\title{
Cytogerontology Since 1881: A Reappraisal of August Weismann and a Review of Modern Progress
}

\author{
Thomas B. L. Kirkwood ${ }^{1}$ and Thomas Cremer $^{2}$ \\ ${ }^{1}$ National Institute for Medical Research, The Ridgeway, Mill Hill, London NW7 IAA, England \\ ${ }^{2}$ Institut für Anthropologie und Humangenetik, Universität Heidelberg, Im Neuenheimer Feld 328, D-6900 Heidelberg, \\ Federal Republic of Germany
}

Summary. Cytogerontology, the science of cellular ageing, originated in 1881 with the prediction by August Weismann that the somatic cells of higher animals have limited division potential. Weismann's prediction was derived by considering the role of natural selection in regulating the duration of an organism's life. For various reasons, Weismann's ideas on ageing fell into neglect following his death in 1914, and cytogerontology has only reappeared as a major research area following the demonstration by Hayflick and Moorhead in the early 1960s that diploid human fibroblasts are restricted to a finite number of divisions in vitro.

In this review we give a detailed account of Weismann's theory, and we reveal that his ideas were both more extensive in their scope and more pertinent to current research than is generally recognised. We also appraise the progress which has been made over the past hundred years in investigating the causes of ageing, with particular emphasis being given to (i) the evolution of ageing, and (ii) ageing at the cellular level. We critically assess the current state of knowledge in these areas and recommend a series of points as primary targets for future research.

\section{Introduction}

In September 1881, August Weismann, Professor of Zoology at the University of Freiburg in Breisgau, delivered a lecture to the Association of German Naturalists on the subject " ̈̈ber die Dauer des Lebens" (The Duration of Life). Except for a brief, unpublished note by A. R. Wallace on the evolution of ageing [circa 1865-1870, cited by editor E. B. Poulton in Weismann (1891), pp. 23-24], Weismann's lecture was the first attempt to explain the ageing and "natural death" of metazoan organisms within the joint framework of (i) the theory of natural selection and (ii) the cell theory. (The term "natural death" was used by Weismann to signify death not caused by accident or other external factor.) In particular, Weismann's arguments led him to propose that the physiological decline which occurs in senile animals results from an evolved limitation to the reproductive potential of somatic cells. These ideas were later published, together with other essays, in German (Weismann 1892a) and in English translation (Weismann 1889, 1892 b).

Weismann died in 1914. For a variety of reasons, his work on cellular ageing has not achieved wide recognition. During the 1880 s, opposition to his view was expressed by Götte (1883) and

Offprint requests to: T. B. L. Kirkwood by Vines (1889), who founded their criticisms on what can now be seen as largely semantic issues concerning the definitions of cell death and immortality. More important, however, than any theoretical objection to Weismann's hypothesis was the claim by Carrel (1912) and his co-worker Ebeling (1913) that they could culture somatic chicken cells and tissue outside the donor organism indefinitely. This claim, which generated remarkable and sustained popular interest (see review by Witkowski 1980), would almost certainly have suppressed further interest in Weismann's apparently false prediction. By the time of Hayflick and Moorhead's (1961) classic discovery that mammalian fibroblasts do, in fact, have finite lifespans in tissue culture, Weismann's prediction was largely forgotten. Indeed, not only was his specific prediction about cellular ageing forgotten, but not long previously his more general viewpoint on the evolution of ageing had been severely criticised by Medawar (1952). In the wake of this, it is perhaps unsurprising that Weismann's gerontological writings, copies of which are relatively hard to obtain, have remained in obscurity and tend nowadays to be cited only in fragmentary form.

In this, the centennial year of his lecture, it is appropriate to re-examine Weismann's theory in more detail and to review how far our understanding of the biology of ageing has progressed over the past one hundred years. Of necessity, such a review must be highly selective, and we have chosen to concentrate on two themes which Weismann himself pioneered: (i) the role of cellular ageing in relation to the ageing of the organism as a whole and (ii) theories on the evolution of ageing in multicellular organisms. We trace the development of research on these two themes from their origin in Weismann's lecture right up to the present state.

Our aims in writing this review are twofold. Firstly, we wish to see Weismann's contribution to the science of gerontology recognised more fully and more accurately than has been the case for many years. Our second, and more important, aim is to stress the relevance of evolutionary theory to present day research on the mechanism of ageing. Weismann clearly appreciated the power of evolutionary argument to make predictions about cellular ageing which are open to experimental test. This paradigm is still very far from being exhausted. Ageing is an intrinsically difficult process to study because so many of the phenomena which can be observed are secondary, not primary. Evolutionary study of the genetic factors which are likely to be involved in regulating the duration of life may, therefore, lead the way to more rapid progress in this field.

We dedicate this review to the memory of George A. Sacher (1917-1981) who, though he disagreed with much of what he 
sometimes termed the "Weismannian paradigm", devoted the greater part of his working life to promoting the importance of an evolutionary and comparative approach to the research of ageing.

\section{Weismann's Theory of Ageing}

As far as possible, we trace the development of Weismann's thoughts with quotations from his own work. In doing so we select from several of his essays, but mainly from those entitled "Über die Dauer des Lebens" (The Duration of Life) (1882), "Über Leben und Tod" (Life and Death) (1984) and "Bemerkungen $z u$ einigen Tagesproblemen" (Remarks on Certain Problems of the Day) (1890). These essays were collected in a book "Aufsätze über Vererbung und verwandte biologische Fragen" (Weismann 1892a), which also appeared in English translation (Essays upon Heredity and Kindred Biological Problems Volume I, 1891, and Volume II, $1892 \mathrm{~b}$, the first edition of Volume I was in fact published in 1889 , but we have access only to the second edition of 1891). If not stated otherwise, page numbers will refer to the English editions. In addition, our presentation of Weismann's theory is based on his books "Das Keimplasma: Eine Theorie der Vererbung" (Weismann 1892c) and "Vorträge über Deszendenztheorie" (Weismann 1913a,b). An extended sample of Weismann's writing, in the form of a reply in Nature to criticism by Vines (1889), is included as an appendix to this paper (Appen$\operatorname{dix} 2)$.

Summarising Weismann's work on ageing is not easy. A prolific author, Weismann wrote at length on a wide range of topics and scattered many of his later thoughts on ageing among essays devoted primarily to other subjects. He also, on occasion, offered more than one explanation for the same phenomenon. A special difficulty with Weismann's early volumes of essays deserves particular mention. In these, he adopted a deliberate policy of publishing previous works with which he no longer fully agreed as an illustration of the "stages in his research". While pointing out in a preface to the English translation that he had deliberately left "certain errors of interpretation" uncorrected, Weismann did not explicitly identify each of these errors. Indeed, an exasperated contemporary (Vines 1889) complained of Weismann's writing that to grasp his point fully and fairly was "a matter of no small difficulty, inasmuch as the argument has to be traced through a number of essays" and that "his statements of opinion are so fluctuating that it is difficult to determine what his opinion exactly is". While we do not share Vines' extreme view, we are aware that in offering a précis of Weismann's theory, we have had to be selective. We trust that by drawing on many different sources from his work we have been able, however, to construct a representative and accurate account.

\section{Preliminary Outline of Weismann's Theory}

The strands of development of Weismann's theory were sufficiently complicated that a preliminary sketch will be helpful. Three main phases of his work can be separated: Phase 1 consists of his first essay "The Duration of Life"; Phase 2 is the essay "Life and Death"; and Phase 3 is the period from the mid-1880s until his death in 1914.

Two concepts persisted without change through all three phases. The first was a conviction that immortality of a higher animal would be a useless luxury without any advantage. The second was belief that the physiological cause of ageing would prove to be a limitation in somatic cells' powers of replication. The variable components of the theory were the steps of argument which led from the former concept to the latter.

Phase 1. In his first essay, the reason suggested by Weismann for the evolution of ageing was an adaptive one, namely that ageing is beneficial in ridding a species of old and decrepit individuals which would otherwise compete for resources with younger ones. Thus, by natural selection the somatic cells of the organism would have come to lose their capacity for unlimited survival, and ageing of the organism as a whole would have appeared. It is this version of his theory for which Weismann is chiefly known today.

Phase 2. In the second essay, while reaffirming the importance of the adaptive argument to explain the origin of natural death in the organism as a whole, Weismann concentrated on the selective process by which somatic cells would have lost their immortality. To explain this, he put forward the essentially non-adaptive view that once immortality of somatic cells ceased to be of any use, there would have been no barrier to selection for specialised characteristics which might have been incompatible with a cell's capacity for indefinite survival. He also raised briefly the possibility that renunciation by somatic cells of their immortality might have resulted in additional material and energy being made available for reproductive cells. In a footnote to the English translation, Weismann commented that this argument could be considered as a particular instance of his general theory of retrogressive evolution, and that the appearance of cellular ageing in higher metazoans could be explained through the same selectively neutral process that he termed "panmixia", whereby cave-dwelling animals may eventually lose the capacity for sight.

Phase 3. In the final phase, spanning the last three decades of his life, Weismann made numerous references to his theory of ageing but did not expound his views again in full. Over this period Weismann related his theory of ageing increasingly closely to his theory of retrogression in nature and less and less to the adaptive argument of Phase 1. However, while it seems that he came eventually to regard panmixia (together with selection for aspects of cell differentiation antagonistic to immortality) as paramount for the introduction of natural death into multicellular species, he never explicitly retracted the adaptive view.

(N.B. Throughout all three phases Weismann held to the belief that duration of life would be precisely regulated by natural selection to provide an optimum for each species. It is important to note that this principle does not by itself have any bearing on whether his theory was adaptive or non-adaptive, an issue which depends solely on the nature of the selection process which was invoked. Our interpretation and use of the terms "adaptive" and "non-adaptive" are defined in Appendix 1.)

To help fix the progression of Weismann's ideas, we have represented it diagrammatically in Fig. 1. In the following two subsections we describe first Weismann's theories on the evolution of ageing, and we then consider his theory of cellular ageing.

\section{Weismann's Thoughts on the Evolution of Ageing}

At the beginning of his lecture in 1881 , Weismann rejected the then prevalent view that differences in longevity between species were determined solely by differences in the general construction of the body, i.e. by morphological and physicochemical 


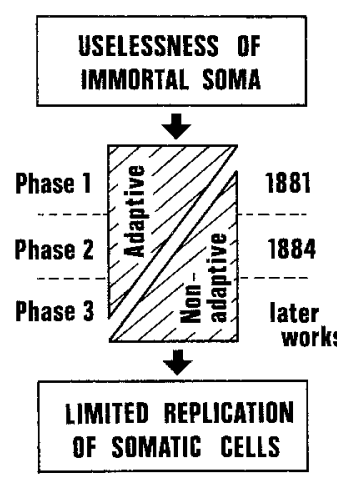

Fig. 1. Diagram of the development of Weismann's theory of cellular ageing. Starting from the observation that immortality of the soma would be of no use to the species, Weismann argued that somatic cells would have come to possess only a finite replicative potential and that this was the cause of ageing. Phases 1-3 (see text) were periods over which the link between these two fixed points of his theory changed from a mainly adaptive argument to a mainly non-adaptive one

attributes. While recognizing the existence, and indeed the need, for correlations of lifespan with factors such as body size, metabolic rate, and physiological complexity, he argued that there were exceptions to invalidate any such general laws:

"In a certain sense it is true that the causes of the duration of life must be contained in the organism itself, and cannot be found in any of its external conditions. But structure and chemical composition ... are not the only factors which determine [it]. ... To put it briefly, I consider that duration of life is really dependent upon adaptation to external conditions, that its length, whether longer or shorter, is governed by the needs of the species, and that it is determined by precisely the same mechanical process of regulation as that by which the structure and functions of an organism are adapted to its environment" (Weismann 1891, pp. 6-10).

As to how this process of adaptation might occur, Weismann turned to Darwin's theory of natural selection. He considered "the body, or soma, ... in a certain sense as a secondary appendage of the real bearer of life,- the reproductive cells" (Weismann 1891, pp. 141-142), and he sought to explain why it was advantageous that the soma should have a limited duration of life. He began by setting out what he saw as the evolutionary role of the individual: "In regulating duration of life, the advantage to the species, and not to the individual, is alone of any importance. ... It is of no importance to the species whether the individual lives longer or shorter, but it is of importance that the individual should be enabled to do its work towards the maintenance of the species. This work is reproduction, or the formation of a sufficient number of new individuals to compensate the species for those which die. As soon as the individual has performed its share in this work of compensation, it ceases to be of any value to the species, it has fulfilled its duty and it may die" (Weismann 1891, p. 10). By defining such a restricted evolutionary role for the individual, Weismann automatically regarded any portion of the lifespan which occurred after production and care of the required quota of offspring as useless. From this it was a relatively easy step to conclude that "life is endowed with a fixed duration, not because it is contrary to its nature to be unlimited, but because the unlimited existence of individuals would be a luxury without any corresponding advantage" (Weismann 1891, p. 25). Weismann later reinforced this view by adding that the perishable and vulnerable nature of the individual was a further reason why it would be useless for nature to endow it with an unlimited duration of life (Weismann 1891, p. 156).

It is interesting to digress briefly here and consider Weismann's view of natural selection a little more closely. It is clear from his writings that he had a general appreciation that it would be through competitive multiplication that some species would survive while others went extinct. However, he plainly did not have more than a rudimentary understanding of the dynamics of this process, nor was he aware of the distinction between selection among species and selection among different variants (genotypes) within a species. This is perhaps unremarkable at a time when the theory of natural selection was still so new (indeed, even now the complexities of natural selection at its different levels of operation are still being unravelled), yet it is surprising that he should not have seen the advantage that could result from an organism doing more than its reproductive duty and contributing to an increase in its numbers. Had he done so, he could not so readily have dismissed the potential usefulness of increased, or indefinite, longevity. Over the same period in England, Galton, Pearson, and others were laying the foundations of their biometric approach to heredity, which was later to be merged, after a period of violent hostility, with the rediscovered Mendelian laws into the discipline of population genetics. However, Weismann was not himself mathematically inclined, and for him, as a physiologically oriented zoologist, natural selection was more a matter of determining the best way of ordering an organism's function and design.

Belief in the uselessness of an immortal soma played a key role as the central tenet of Weismann's thoughts on ageing throughout the remainder of his work. From this starting point his theories diverged in different directions, first mainly adaptive and later mainly non-adaptive. The question he sought to answer was thus the relatively simple one of why the redundant portion of the lifespan-that which follows the completion of reproductive duty - should be lost.

\section{a) The Adaptive Explanation}

Weismann first proposed that immortality of a higher animal would be positively harmful to its species and therefore prevented by natural selection: "Suppose that an immortal individual could escape all fatal accidents, through infinite time, - a supposition which is of course hardly conceivable. The individual would nevertheless be unable to avoid, from time to time, slight injuries to one or other part of its body. The injured parts could not regain their former integrity, and thus the longer the individual lived, the more defective and crippled it would become, and the less perfectly would it fulfil the purpose of its species. Individuals are injured by the operation of external forces and for this reason alone it is necessary that new and perfect individuals should continually arise and take their place, and this necessity would remain even if the individuals possessed the power of living eternally. From this follows, on the one hand the necessity of reproduction and on the other the utility of death. Worn out individuals are not only valueless to the species, but they are even harmful, for they take the place of those which are sound. Hence by the operation of natural selection, the life of our hypothetically immortal individual would be shortened by the amount which was useless to the species" (Weismann 1891, pp. 24-25).

The critical point in this argument was Weismann's supposition that perfect repair of minor injuries is impossible. Failure to justify this assumption rendered the explanation 
circular, as Medawar (1952) was later to point out: "Weismann assumes that the elders of his race are worn out and decrepitthe very state of affairs whose origin he purports to be inferring-and then proceeds to argue that because these dotard animals are taking the place of the sound ones, so therefore the sound ones must by natural selection dispossess the old".

The adaptive theory was reiterated in Weismann's second essay on ageing (Weismann 1891, p. 136) but was relegated to a secondary role (Weismann 1891, pp. 155-156) and never subsequently repeated. It is doubtful whether Weismann ever saw clearly its logical faults (see also Section 3), but he turned his attention from it to a principally non-adaptive view.

\section{b) The Non-adaptive Explanation}

The central component of Weismann's non-adaptive theory of ageing was the principle of panmixia which he developed in his essay "On Heredity" (Weismann 1891, pp. 85-91) and expounded more fully in "Retrogressive Development in Nature" (Weismann 1892b, pp.3-30; compare also Weismann 1913b, pp. 108-114). In brief, this principle states that as soon as any character becomes useless to an organism, natural selection ceases to operate upon it and it begins to disappear. "When this process is in operation, not only those individuals with the best developed organs have the chance of reproducing themselves, but also those individuals in which the organs are less well developed. Hence follows a mixture of all possible degrees of perfection, which must in the course of time result in the deterioration of the average development of the organ. Thus a species which has retired into dark caverns must necessarily come to gradually possess less developed powers of vision; for defects in the structure of eyes, which occur in consequence of individual variability, are not eliminated, but may be transmitted and fixed in the descendants. This result is all the more likely to happen, inasmuch as other organs which are of importance for the life of the species will gain what the functionless organ loses in size and nutrition" (Weismann 1891, p. 299).

(The last sentence of this extract contains an important principle first stated by Darwin (1872) and well recognised by Weismann, namely that natural selection will always operate so as to ensure the most favourable allocation of material and energy to the different parts of the body. Thus, while panmixia itself is selectively neutral, positive selection of this kind may accelerate the retrogression of useless organs and functions. As we shall see in Section 3, this principle can be generalised to provide the basis for a comprehensive theory of the evolution of ageing.)

Weismann's non-adaptive explanation for the origin of natural death in multicellular organisms arose from applying panmixia to the supposedly useless period of life which followed the completion of reproductive duty. At first, the argument was used merely to justify the hypothesis of cellular ageing (see below), while the adaptive theory was retained to explain the existence (and, in particular, the persistence) of a finite duration of life for the organism as a whole. Soon, however, Weismann realised that panmixia was sufficient by itself to explain the evolution of ageing, especially if reinforced by positive selection for attributes such as greater cell specialisation or increased structural complexity, which he felt were unlikely to be consistent within definite duration of life.

Towards the end of his life, in his lectures on "Deszendenztheorie", Weismann explicitly integrated his theory of ageing into the general framework of his theory of retrogression (Weismann 1913a, pp. 213-217). He stated that his early attempts to explain the evolution of ageing were misguided ("meine damaligen Fehlgänge"; regrettably these errors were again left unspecified) and suggested that the "true reason" for its evolution was that "each function and each organ disappears as soon as it becomes superfluous for the maintenance of the species". In this way, he had justified for himself the assertion with which he opened his lecture in 1881, namely that duration of life is regulated in precisely the same way that the structure and functions of an organism are adapted to its environment. Too short a lifespan, and natural selection would clearly tend to increase it; needlessly long a lifespan, and the excess would disappear by retrogression. All that was lacking was any clear proposal as to what might be the mechanism on which this selective control would actually operate.

In concluding this subsection, it should be emphasised that even though Weismann regarded it as possible, or even probable, that positive selection played a part in promoting the retrogression from hypothetical immortality to a finite duration of life, the explanation of ageing described here was a genuinely non-adaptive one (see Appendix 1). In contrast with his earlier adaptive argument, Weismann was not assuming an intrinsic advantage in the process of ageing itself. However, he did not himself make this distinction clear.

\section{Weismann's Theory of Cellular Ageing}

As a practical zoologist, Weismann was keenly interested in the physiological processes by which the duration of life is regulated. Observing that with advancing age the functions of tissues and organs become diminished, and noticing that cell renewal plays an important part in many vital processes, Weismann suggested that the origin of "natural death" lies in the limitation of somatic cells' powers of reproduction.

By invoking panmixia, Weismann reasoned that the useless, or even undesirable, nature of somatic immortality would render cell renewal redundant, and therefore subject to loss, after production of the required quota of offspring. He proposed that the physiological basis of senescence is that "death takes place because a worn-out tissue cannot for ever renew itself, and because a capacity for increase by means of cell-division is not everlasting, but finite" (Weismann 1891, p. 21), and he justified this hypothesis by suggesting that "the organism did not finally cease to renew the worn-out cell material because the nature of the cells did not permit them to multiply indefinitely, but because the power of multiplying indefinitely was lost when it ceased to be of use" (Weismann 1891, p. 25).

Weismann was well aware that while a finite replicative lifespan might be characteristic of the majority of cells in higher organisms, the replicative potential of the cells of the germ line must necessarily remain unlimited, or the species would not be preserved. Therefore, he went to some length in discussing the distinction between cells which belong to the germ line and cells which do not (Weismann 1891, pp. 140-155, 163-256; 1892c, pp. 253-301). Lacking knowledge of the nature of genes and of the regulation of cell differentiation, Weismann's concept of the physiological difference between somatic and germ cells, based on his theory of the "germ plasm", is now outdated. Nevertheless, his appreciation of the functional difference between them was profound, and he was alert to the problems presented by plants and simple animals, such as hydroids, in which almost any part is capable of generating a new individual. For these types of organism where the distinction between cells of the germ 


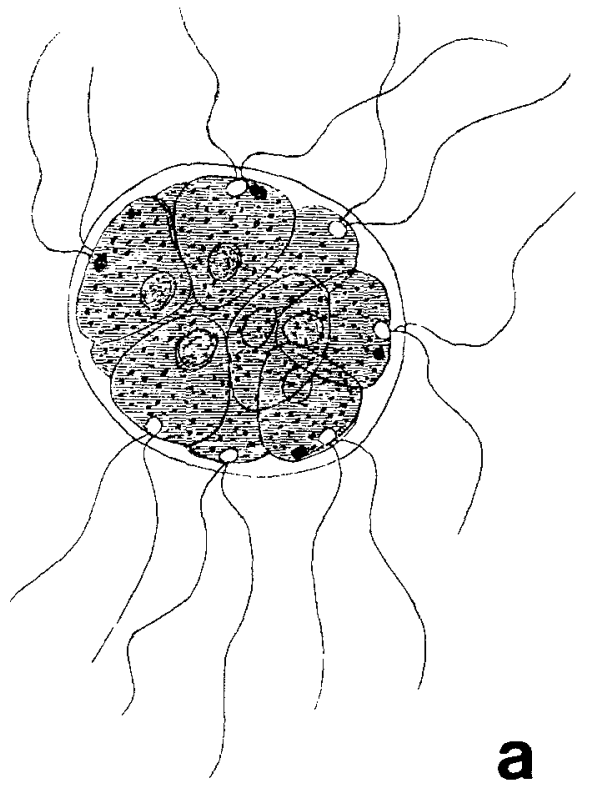

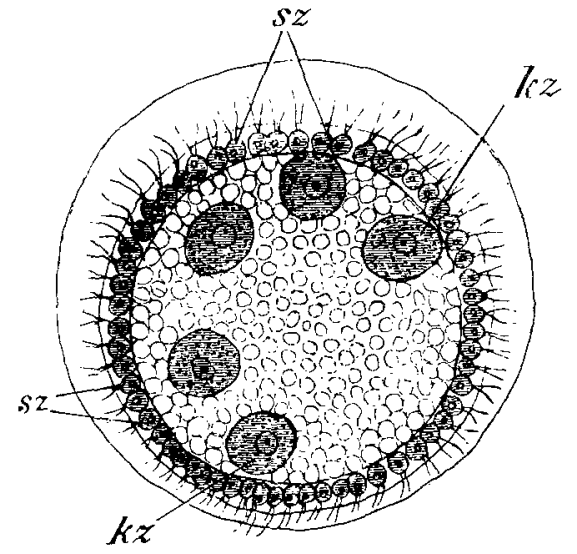

b
Fig. 2a and b. Drawings of Volvocinean species Pandorina morum (a) and Volvox minor (b) are reproduced (with kind permission from the Gustav Fischer Verlag, Stuttgart) from Weismann (1892a), p. 245. Weismann used these two closely related genera to illustrate the difference between a "homoplastid", i.e. a cell colony made up of equal cells as in P. monum, and a "heteroplastid", i.e. a cell colony composed of both germ cells (kz) and somatic cells (sz) as in V. minor. In Pandorina, each cell acts as a reproductive cell and is potentially immortal, while in Volvox only the germ cells have retained this attribute, the somatic cells being subject to natural death. Volvox minor is a semelparous species (see Section 5), i.e. it reproduces only once, after which the soma dies line and cells serving exclusively somatic functions is unclear, Weismann's argument for the evolution of a finite replicative potential of somatic cells does not apply (see also Section 5).

The presentation by Weismann of an evolutionary scenario for the appearance of ageing in higher metazoans reveals clearly his view of the origin of cellular ageing: "Let us now consider how it happened that the multicellular animals and plants, which arose from unicellular forms of life came to lose this power of living for ever. The answer to this question is closely bound up with the principle of division of labour ... the first multicellular organism was probably a cluster of similar cells, but these units soon lost their original homogeneity ... the single group would come to be divided into two groups of cells, which may be called somatic and reproductive. As the complexity of the metazoan body increased, the two groups of cells became more sharply separated from each other. Very soon the somatic cells surpassed the reproductive in number, and during this increase they became more and more broken up by the division of labour into sharply separated systems of tissues. As these changes took place, the power of reproducing large parts of the organism was lost, while the power of reproducing the whole individual became concentrated in the reproductive cells alone. But it does not therefore follow that the somatic cells were compelled to lose the power of unlimited cell reproduction" (Weismann 1891, pp. 27-28).

"The problem is very easily solved if we seek assistance from the principle of panmixia. ... As soon as the immortality of somatic cells became useless they would begin to lose this attribute. The process would take place more quickly, as the histological differentiation of the somatic cells became more useful and complete. ... If this became true of the whole mass of somatic cells, we should meet with natural death for the first time. Whether we ought to regard this limitation of life of the specific somatic cells as a mere consequence of their differentiation, or at the same time as a consequence of the powers of natural selection especially directed to such an end,-appears doubtful. But I myself am inclined to take the latter view ${ }^{1}$, for if it was

1 At this point Weismann seems to imply an adaptive role for cellular ageing ("... selection especially directed to such an end..."). However, in the next paragraph the causes which he suggests for its evolution are all non-adaptive advantageous to the somatic cells to preserve the unending life of their ancestors - the unicellular organisms, this end might have been achieved, just as it was possible at a later period, in the higher metazoan, to prolong both the duration of life and of reproduction a hundred- or a thousand-fold. At any rate, no reason can be given which would demonstrate the impossibility of such an achievement.

With our inadequate knowledge it is difficult to surmise the immediate causes of such a selective process. Who can point out with any feeling of confidence the direct advantages in which somatic cells, capable of limited duration, excelled those capable of eternal duration? Perhaps it was in a better performance of their special physiological tasks, perhaps in additonal material and energy available for the reproductive cells as a result of this renunciation of the somatic cells; or perhaps such additional power conferred upon the whole organism a greater power of resistance in the struggle for existence, than it would have had, if it had been necessary to regulate all the cells to a corresponding duration" (Weismann 1891, pp. 141-142).

In these passages we can see that while cellular ageing is ascribed by Weismann primarily to the wasting effect of panmixia, he also recognized that the evolution of a finite replicative lifespan in somatic cells may be accelerated indirectly by selection for some other attribute. This is an important concept to which we shall return when reviewing later work.

Finally, we should note that Weismann gave thought to (i) how the longevity of the soma as a whole might relate to the replicative capacity of individual cells and (ii) how his prediction could be tested. On the former point he noted that his hypothesis of a cellular basis for ageing "does not, however, imply that the immediate cause of death lies in the imperfect renewal of cells, for death would in all cases occur long before the reproductive power of the cells had been completely exhausted. Functional disturbances will appear as soon as the rate at which the worn-out cells are renewed becomes slow and insufficient" (Weismann 1891, pp. 21-22). He also recognised that differences in longevity between species should be reflected by differences in the replicative potential of their somatic cells. To test the validity of his theory, he wrote that it would be necessary "to supply evidence that the mode and quantity of [cellular] reproduction depends in fact on the specific nature of the cell itself and is in no 
way exclusively determined by its nutriement" (Weismann 1892a, p. 34). Means to carry out such tests were not available at that time.

\section{Theories on Evolution of Ageing after Weismann}

Following Weismann, a long period elapsed before any major attempt was made to re-examine the evolution of ageing in metazoans. During this time, various general theories as to the nature of the ageing process were put forward (for reviews see Medawar 1946 and Comfort 1979), but these placed little emphasis on the influence of natural selection. Prominent among them were (i) the "optimistic studies" of Metchnikoff (1907) who sought to relate ageing to the influence of invading poisons, supposed to originate mainly from microbes in the gut; (ii) the view that ageing is related directly to growth, either through the differentiation of cells into terminal forms incapable of growth or repair (Minot 1907), or as a by-product of the continued action of the mechanism to limit growth as soon as specific size is reached (Bidder 1932) ${ }^{2}$; (iii) the hypothesis of Child (1915), based largely on extensive experimental research with planaria (Child 1911), that ageing is associated with a decrease in the rate of metabolism which results in the accumulation within the cell of "structural obstacles to metabolism" such as inactive wastes; and (iv) the "rate of living" theory of Pearl(1928), who proposed that the duration of life varies in inverse proportion to the rate of energy expenditure as a result of a finite total amount of "vitality" being used up. Metchnikoff, Minot, and Child all made reference to Weismann, though only Child paid any attention to the evolutionary aspect of his work, and Minot ascribed to him simply the view that duration of life is determined by the rate of wearing out of the body.

\section{Accumulation of Late-Acting Deleterious Genes}

The evolutionary basis of ageing was first seriously re-examined by Medawar (1952), following brief discussion by Haldane (1941). During the intervening decades, the theory of natural selection had been considerably refined and formalised in association with the development of Mendelian genetics. Medawar's theory was correspondingly more quantitative in its formulation than Weismann's.

Medawar observed that even without ageing, the cumulative effect of accidental mortality (by starvation, predation, disease, etc.) is to reduce progressively the fraction of individuals surviving to older and older ages. Any new gene arising by mutation within the population and having an age-specific time of onset will, therefore, affect either a large or small proportion of individuals bearing that gene according to whether it acts early or late. In general, natural selection will tend to bring forward the time of expression of "good" genes and delay the time of expression of "bad" genes (see Fig. 3). Any bad gene which is expressed at a very late age, when the fraction of survivors is negligible, will be subject to little or no selection at all. [Strictly, as Williams (1957) pointed out, it is not the fraction of survivors per se which matters, but the remaining fraction of average reproductive potential. This is because natural selection operates through differences in reproductive success. Thus, the force of natural selection does not start to decline until

2 Bidder's hypothesis was, to some extent, anticipated by Weismann (1891, pp. 31-33), who suggested that "the limitations of the organism in both space and time [could be reduced] to one and the same principle", namely a finite capacity for cell multiplication

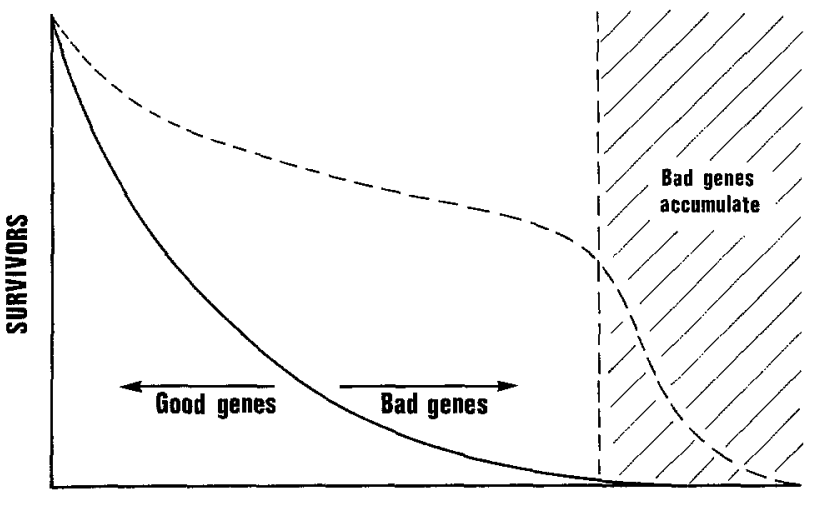

AGE

Fig. 3. Medawar's (1952) theory of the evolution of ageing suggests that genes with age-specific effects are advanced or postponed in their time of expression according to whether they are beneficial or harmful. Harmful genes which are expressed at such late ages that the normal, wild survival curve (continuous curve) has fallen almost to zero can accumulate in the population with little or no selective check. Ageing occurs in protected environments when mortality is reduced and the early part of the survival curve (dashed curve) is raised so that a significant proportion of individuals encounter the accumulation of lateacting harmful genes

reproduction begins, at or soon after the age of maturation. For a species which reproduces repeatedly during its lifespan, adult survivorship and residual reproductive potential are closely related, but this is not the same for species which reproduce only once (see Section 5). Discussion in this section is confined to species like mammals, birds, and reptiles, which reproduce repeatedly. For further consideration of this point see Kirkwood and Holliday (1979).]

Medawar suggested, therefore, that there would accumulate a "genetic dustbin" of deleterious mutations with very late agespecific effects and that these are responsible for ageing. In the normal, wild environment the gross effects of ageing are rarely seen because individuals mostly succumb to accidental death too soon. Senescence becomes manifest only when, either by chance or because it is protected, an individual survives long enough to run into the accumulation of harmful late-acting genes.

In Medawar's theory, no advantage of any kind is attributed to the process of senescence, nor is it linked with any beneficial trait. Ageing is hypothesised simply to be the result of a decline with age in the corrective power of natural selection. Interestingly, this is quite close to Weismann's explanation of ageing in terms of panmixia, the main difference being that in Medawar's view the selective advantage of indefinite longevity is negligible because of the environmental hazards to which natural populations are exposed, whereas to Weismann immortality appeared useless primarily because he regarded the completion of an individual's "reproductive duty" as eliminating any value in its continued survival.

\section{Pleiotropic Genes and Ageing}

Williams (1957) put forward a hypothesis which was similar to Medawar's in recognising that the force of natural selection declines with age, but in which ageing was attributed to pleiotropic genes that have good effects early in life but become harmful later. By essentially the same argument as that offered by Medawar, Williams proposed that ageing could be explained as the cumulative result of deleterious late gene effects which were beyond the reach of negative selection. The important 


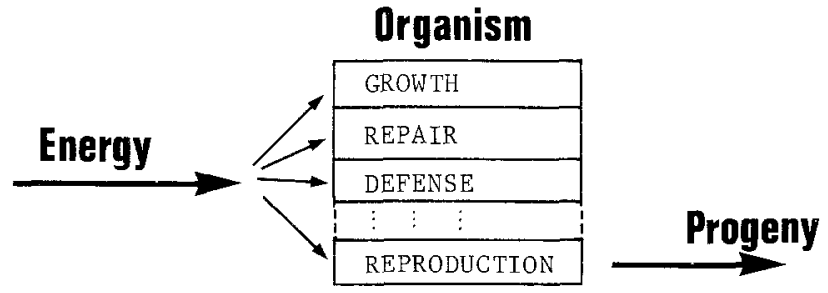

Fig. 4. An organism may be viewed as an entity which transforms energy from its environment into its progeny. The intake of energy must be allocated among different metabolic activities, some of which are shown in the diagram

novelty in Williams's theory, though, was the assumption that the genes responsible for senescence also have good effects, with ageing thus being seen as a by-product of positive selection for other traits.

More recently, mathematical analyses of the rules governing selection of genes with age-specific effects on survivorship have supported Williams's hypothesis (Hamilton 1966; Charlesworth 1980), and some experimental data have been obtained which suggest that pleiotropic genes of the sort postulated by Williams may exist (Rose and Charlesworth 1980). Also, in Rose and Charlesworth's experiments, which involved selection on lifehistory components in Drosophila melanogaster, no evidence was found of the increase in additive genetic variance with age, which is predicted by Medawar's version of the theory.

\section{Disposable Soma Theory of Ageing}

A somewhat different explanation for the evolution of ageing is the "disposable soma" theory, proposed originally in a specific cellular form (Kirkwood 1977; Kirkwood and Holliday 1979) and developed more generally recently (Kirkwood 1981). The disposable soma theory stems from the observations that (i) as noted by Weismann, the soma is a side branch off the main sequence of life, the germ line, and (ii) an organism, to maximise its fitness, must optimally allocate its resources (primarily its intake of energy) among a variety of metabolic compartments (see Fig. 4). The kernel of the theory is the observation that for a higher organism which reproduces repeatedly, the optimum allocation of energy involves a smaller investment in somatic maintenance and repair than would be required for the soma to last indefinitely. The disposable soma theory therefore predicts that there will be an accumulation through life of unrepaired somatic damage and that this is what causes senile degeneration and, ultimately, death.

The argument to support the theory runs as follows: Given the continual hazard of accidental death, from which no species can be entirely immune, each individual soma would have only a finite expectation of life, even if it were not subject to senescence. When the soma dies, the resources invested in its maintenance are lost. Too low an investment in repair is obviously unsatisfactory because then the soma may disintegrate before it can - reproduce. However, too high an investment in repair is also wasteful because there is no advantage in repairing the soma better than is necessary for it to survive its expected lifetime in the wild environment in reasonably sound condition. Fitness in the latter case would actually be enhanced by reducing the investment in repair and channelling the extra energy into, for example, more rapid growth or greater reproductive output. Fitness is therefore maximised at a level of repair which is less than that which would be required for indefinite somatic survival

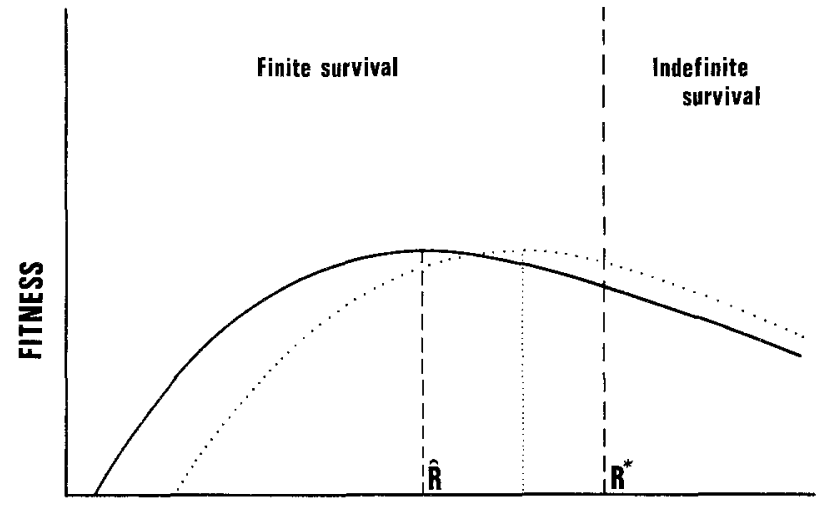

INVESTMENT IN REPAIR, $R$

Fig. 5. Theoretical relationship between fitness and the level of investment of resources in somatic repair for species which reproduce repeatedly during the lifespan. The disposable soma theory (see text) predicts that the optimum level of investment in repair, i.e. that which maximises fitness, will be less than the minimum required for indefinite somatic survival. The exact optimum depends on a species' ecological niche, and particularly, on its rate of accidental mortality. For a species subject to high accidental mortality (continuous curve) the optimum will generally be lower than for a species subject to low mortality (dotted curve)

(see Fig. 5). It should be noted that there is no assumption in the theory that energy is necessarily very scarce. While energy may, of course, frequently be in short supply, the argument concerns only the allocation of that which is available. The disposable soma theory applies, therefore, even when there is an abundance of energy since under such circumstances it should still be preferable to invest extra resources in reproduction or other fitnessenhancing activities rather than in somatic repair.

The actual optimum level of investment in repair will depend on the species' ecological niche. For example, a species subject to high environmental mortality will do better not to invest too heavily in each individual soma, which will therefore age relatively soon, but should concentrate its effort instead on more rapid and prolific reproduction. Conversely, a species which experiences low accidental mortality may profit by doing the reverse. In either case, the level of investment in somatic repair will generally be such that obvious signs of ageing are not commonly seen in natural populations.

The disposable soma theory thus not only explains the wellknown inverse correlations between longevity and fecundity, but it also makes explicit predictions which are relevant to the research of ageing. Firstly, it predicts that ageing is the result of an accumulation of somatic damage and thus defines a paradigm within which investigations into the changes that occur during ageing can be integrally co-ordinated. Secondly, it predicts that species with different longevities should exhibit corresponding differences in their levels of somatic repair. By comparative study of the efficiency of different repair systems (as, for example, by Hart and Setlow 1974), this prediction may be tested and, if the theory proves to be correct, it may be possible to identify those repair processes which are primarily responsible for regulating the duration of life.

The paradigm generated by the disposable soma theory also embraces a number of other views. Firstly, the theory can be related to Williams's pleiotropic gene hypothesis, the genes in question being those which control the levels of somatic repair. In this case the good and bad effects of a reduced level of repair are, respectively, increased reproduction and earlier somatic 
decay. Secondly, the theory provides an evolutionary backdrop for each of several specific hypotheses which postulate particular kinds of somatic damage as the cause of ageing (see Section 4 and Kirkwood 1981). Thirdly, it offers a resolution in evolutionary terms of the arguments for and against generalised "wear and tear" explanations of ageing. In the view of the theory, ageing is indeed attributed to wear and tear, not however because wear and tear is inevitable (organisms are, after all, thermodynamically open systems which can in principle use the energy of their surroundings to combat increase in their entropy), but instead as the indirect result of evolutionary optimisation of the balance between somatic repair and reproduction. The theory therefore encompasses within a more general framework the views of Sacher (1978) and Cutler (1978) in which ageing is regarded as inevitable in a complex metazoan. These authors, who have concentrated on the more restricted question of how natural selection controls the rate at which senescence occurs, have similarly predicted a positive correlation between somatic repair and longevity. The disposable soma theory, however, goes further in also explaining why higher metazoans have not followed an evolutionary path which might have permitted them indefinite survival.

\section{Adaptive Theories of Ageing}

The theories which have been reviewed in this section so far have all been non-adaptive, ageing being seen either as a consequence of the failure of natural selection to prevent it or as a by-product of selection for other traits. The view that ageing is adaptive remains, however, widely popular and is implicit in much current gerontological research. The attraction of this view is that it permits ageing to be regarded as a programmed ${ }^{3}$ process under the same strict genetic control as, for example, morphogenesis. All that is required then in order to understand, and perhaps manipulate, the ageing process is to unravel the details of the programme.

Despite the popularity of this adaptive view, remarkably few authors have sought to justify it explicitly in evolutionary terms. Such attempts as have been made have suggested, for example, that ageing is needed to guarantee or to accelerate the turnover of generations so as to improve a species' chance of adapting to changes in its environment (Woolhouse 1967). However, any adaptive theory of ageing is faced with acute difficulties. Firstly, as Medawar observed, accidental mortality is sufficiently high in most species that obvious senility is rarely seen in wild populations (Medawar 1952; Lack 1954). Thus, there is neither any need for a mechanism specifically to terminate life, nor opportunity for it to evolve. Secondly, for ageing to have evolved as an adaptive trait would have required that selection for advantage to the species or group was more effective than selection among individuals within the group for the reproductive advantages of a longer life. Superiority of the former kind of selection over the latter is very seldom the case (Maynard Smith 1976). Thus, while there may be a few special circumstances in which an adaptive explanation of ageing could hold (Kirkwood and Holliday 1979), such instances will be extremely rare.

\section{Modern Cytogerontology ${ }^{4}$}

Carrel's view on the immortality of somatic cells in vitro remained dominant for almost half a century and during this period led gerontologists away from specifically cellular theories of ageing (see Medawar 1946; Maynard Smith 1962). Despite frequent failures to maintain cells growing indefinitely in culture, it took until the late 1950 s before the ready explanation that these difficulties were due to inadequacies of culture technique was seriously challenged (Swim and Parker 1957). The careful experiments of Hayflick and Moorhead (1961) and Hayflick (1965) finally established that Carrel's assertion had been wrong (for a penetrating enquiry into the possible reasons for this, see Witkowski 1980) and opened fresh speculation into the possibility that ageing might be due to intrinsic limitations in the lifespan of somatic cells.

\section{Do Somatic Cells Really Age?}

It is now widely accepted that normal (i.e. diploid) mammalian, avian, and (probably) reptilian fibroblasts can undergo only a finite number of cell divisions in vitro (see, for example, Hayflick 1977 or Martin 1977a), although heteroploid transformed cells generally seem to multiply indefinitely. For human embryonic fibroblasts the number of cell population doublings attainable under normal culture conditions is about $50 \pm 10$ (Hayflick 1977). It has also been shown that adult human glia-like cells invariably enter a phase of irreversible degeneration, similar to that seen in fibroblasts, after approximately 15 population doublings in vitro (Ponten and Westermark 1980).

The possibility that the limitation of growth in vitro is due to artifacts of tissue culture, and is not intrinsic to the cells themselves, has largely been dispelled by careful elimination of the likely deficiencies of culture systems. In addition, there is evidence from serial transplantation experiments that several kinds of replicative cells exhibit only a finite division potential in vivo. Using skin transplants from inbred strains of mice, Krohn (1962) showed that pieces of skin could be passed successively from one mouse to another for a period longer than the lifetime of any single individual, but that eventually the grafts began to decrease in size and became unsuitable for further transplantation. Similarly, serial transplantation in mice of mammary gland tissue (Daniel 1973), haematopoietic cells (Ogden and Micklem 1976), and antibody-producing cells (Williamson and Askonas 1972) could be carried out through several passages, but then the cells died out.

Several diverse studies have sought to explore the link between loss of division capacity in somatic cells and ageing of the organism as a whole. If cells stop dividing in culture because they have used up an intrinsic maximum number of divisions, then their in vitro lifespan should decrease in inverse relation to the age of the donor from whom they are taken. A cross-sectional study by Martin et al. (1970) revealed such an effect, with an average reduction in lifespan of 0.2 population doublings per year of age, although there was considerable variability within each age group. A similar difference was also reported in a comparison of cultures from young (21-36 years) and old (6392 years) donors (Schneider and Mitsui 1976). A further correlation between in vitro and in vivo ageing was found by Smith et al. (1978) in studies on age-related changes in colony size distributions among individual fibroblasts.

One particularly interesting finding of Martin et al. (1970) was that cells from patients with Werner's syndrome, a genetically determined disorder which in many respects resem-

\footnotetext{
3 For a precise definition of what we mean by "programmed", see Appendix 1

4 The term "cytogerontology" was coined by L. Hayflick in 1974
} 
bles an acceleration of normal ageing (Epstein et al. 1966), had markedly reduced in vitro doubling potentials. This observation has been confirmed by other workers (Stecker and Gardner 1970; Nienhaus et al. 1971; Holliday et al. 1974).

Another consequence of the hypothesis that failure of cell replication plays a part in ageing is that cell culture lifespans should be positively correlated with species longevity. Such an association has been claimed (e.g. Hayflick 1977), and it is clearly true for the two most extensively studied mammals, mice and humans. Diploid embryonic mouse fibroblasts can undergo only 14-28 population doublings in vitro (Rothfels et al. 1963; Todaro and Green 1963), which, even allowing for the disparity in body size, is substantially less than the 50 or so for human fibroblasts. The maximum longevity of mice is 3.5 years compared with 110 years for humans. However, comparative studies by Stanley et al. (1975) failed to confirm this general pattern among other mammals. Clearly, there are difficulties in reaching firm conclusions from interspecies comparisons when factors such as age, biopsy site, and the relative suitability of the culture systems are hard to control. Nevertheless, it is obviously of considerable importance to resolve this issue, and more extensive studies, preferably using cells from a carefully defined source (e.g. foetal lung), should be carried out.

A feature that must be taken into account in any meaningful investigation into factors affecting in vitro lifespan is the considerable variability in replicative potential both of mass cultures (Holliday et al. 1977) and of individual cells within a population (Martin et al. 1974; Smith and Hayflick 1974; Smith and Whitney 1980). Variability of only a few population doublings represents a sizeable difference in total cell multiplication.

Variation in the lifespan of mass culture requires that several replicate cultures are grown before in vitro lifespan can reliably be determined. If different cell donors are to be compared, account should also be taken of the considerable variation in division potential of cells from one biopsy site to another (Martin 1977a) or even from one piece of a single biopsy to another (Thompson and Holliday, in preparation).

Variation between individual cells can have profound implications for the growth of mass cultures and for theories on mechanisms of ageing (Martin et al. 1974; Kirkwood and Holliday 1975; Harley and Goldstein 1978; Smith and Whitney 1980). In particular, the possibility that there can exist a few cells with very much higher division potential than the average makes the overall lifespan of the culture dependent on its composition and size. An extreme example of this is the commitment theory of cellular ageing (Kirkwood and Holliday 1975), in which it is suggested that there are cells which initially have the capacity for unlimited division, but which may become committed, at random, to only a finite division potential ${ }^{5}$. Under normal culture conditions, the theory predicts that uncommitted cells are "diluted" by committed ones and will eventually be lost, resulting in finite growth of the mass culture. A consequence of the theory is that culture size should affect in vitro lifespan by influencing the time at which uncommitted cells are finally diluted out. Experimental tests of this and other predictions have given support to the commitment theory (Holliday et al. 1977,

\footnotetext{
5 The commitment theory is concerned primarily with the finite growth of cell populations in vitro. It is thus not directly connected with ageing in vivo although a possible link has been suggested by Kirkwood (1977) which also relates to the observation (discussed below) that the number of cell doublings in vitro considerably exceeds that which is required in vivo
}

1981) and, in particular, a reduction in culture size has been shown to reduce lifespan. Data consistent with a dilution out of uncommitted cells have also been reported by Zavala et al. (1978; see Holliday et al. 1977 for discussion).

An important implication of the commitment theory is that, if it is valid, finite growth is not necessarily an intrinsic property of fibroblast cultures. In a sufficiently large population of cells (for human fibroblasts this is estimated to be at least $10^{10}$ ) the progressive dilution of uncommitted cells will cease before they are lost, and if uncommitted cells really can multiply indefinitely, the population will thereafter grow indefinitely, or at least until random loss of all uncommitted cells occurs at some subculture. In this strictly limited sense, it is possible, therefore, that the ultimate cessation of fibroblast growth is an artifact of the population dynamics imposed by cell culture routine. This does not, however, invalidate the fibroblast system as a model for cellular ageing. Instead, it focuses attention on the need to consider events taking place in the lineages of the individual cells which make up the cultures.

For this and other obvious reasons, a direct equation between ageing in vivo and the final cessation of growth of cells in vitro does not make sense. Fifty population doublings will generate far more cells than could possibly be required in an individual lifetime. The data of Martin et al. (1970) indicate that cells from very old humans can still undergo at least 20 population doublings in vivo. This is perhaps unsurprising since, as recognised by Weismann (see above), death would always take place long before the replicative capacity of somatic cells was fully exhausted. The growth kinetics of cell populations in vivo, their interactions with each other, and their patterns of proliferation (see Kay 1965) are likely to be considerably more complex than those in vitro. Nevertheless, there is good reason to believe that an understanding of why cells finally cease dividing after doing so for long periods in culture will throw light on basic features of ageing as it occurs at the cellular level.

So far, we have considered only replicative cells. A substantial proportion of somatic cells are, of course, either postreplicative or divide only rarely. Although not considered by Weismann, the possibility obviously exists that ageing may be due, at least in part, to the cumulative loss, or progressive malfunction, of these types of cells. This idea is popular among gerontologists, and numerous studies have shown evidence of age-associated changes in post-replicative cells (see review by Martin 1977b). On the basis of present knowledge, it seems that any attempt to establish the primacy of either replicative or postreplicative cells as determinants of organismic longevity would be in vain. In both cases, after a prolonged period of healthy operation, the cell seems to undergo some loss of function with increasing age, whether or not its function includes mitosis. Clearly, it is important to try to elucidate the molecular and genetic mechanisms underlying this deterioration.

\section{Mechanisms of Cellular Ageing}

A wide range of mechanisms has been postulated to explain a cell's loss of function with age. Some of these implicate quite specific sources of damage, for example macromolecular crosslinkage (Bjorksten 1968), accumulation of toxic metabolic wastes (Sheldrake 1974), racemisation of amino acids (De Long and Poplin 1977), macromolecular damage caused by free radicals (Harman 1956), or the accumulation of defects in cell membranes (Zs-Nagy 1978; Cremer et al. 1981). Others are more general, such as the somatic mutation theory (Szilard 1959; 
Curtis 1966; Burnet 1974) or the protein error theory (Medvedev 1962; Orgel 1963, 1973). Each of these mechanisms presupposes that ageing is a process of stochastic cellular deterioration, albeit at a rate which may be genetically controlled through the efficiency of repair mechanisms. Other authors dismiss this view altogether and regard cellular ageing as a programmed phenomenon regulated in a manner similar to development (e.g. Hill and Franks 1977).

An issue which has sparked considerable controversy is whether replicative cells, in particular fibroblasts, cease dividing simply because they age, or because they undergo differentiation into a terminal post-mitotic state (Martin et al. 1974; Bell et al. 1978). If the latter, it has been suggested that these cells do not truly age until they are in their terminally differentiated state, and even that they decay then only because present culture systems favour proliferating, and not differentiated, cells (Bell et al. 1978). At present, evidence offered in support of the terminal differentiation hypothesis is based mainly on morphological criteria (Martin et al. 1974; Kontermann and Bayreuther 1979).

The opposite view, that fibroblasts do genuinely age, is supported by the evolutionary argument of the disposable soma theory, which predicts a progressive accumulation of generalised damage in somatic cells, whether or not they are dividing and/or differentiating (Kirkwood 1981). Certainly, a very broad spectrum of changes, many of them degenerative, are seen in somatic cells as time passes (Martin 1977a, 1977b; Hayflick 1977). The two hypotheses are not, in fact, mutually exclusive since cells may deteriorate even as they pass through further stages of differentiation, and this issue is likely only to be ultimately resolved when the molecular basis of the process is known in more detail.

A considerable difficulty, when confronted with the multitude of age-related cellular changes, is to determine which of them are primary and which are secondary. As pointed out by Martin (1977b), the most powerful approach - a direct genetic analysis of factors affecting longevity-ought soon to be possible. In the meantime, however, two other lines of attack can be exploited. The first of these is to use cell micro-manipulation techniques to localise the determinants of ageing within the cell. If control of ageing were shown to reside entirely within the cell nucleus, then the terminal-differentiation/programmed-ageing hypothesis would be supported. Alternatively, if the cytoplasm were shown to be the dominant site of ageing, then random damage theories would be favoured. An elegant series of experiments by Muggleton-Harris and Hayflick (1976) in which whole cells were reconstructed by fusing isolated karyoplasts (nuclei with very limited amounts of cytoplasm) and cytoplasts (enucleated cells) gave equivocal results, since it was found that only young karyoplasts and young cytoplasts together could form cells capable of subculture. Thus, ageing seems to involve both nucleus and cytoplasm.

The second approach to the problem of primacy involves a degree of a priori reasoning and obviously must be used with caution. Among alternative ageing mechanisms, some are more basic than others. A population genetic study of the rapid rate of evolution of human longevity suggests that the number of genes governing the rate of ageing is quite small (Cutler 1975). Therefore, a research strategy which, in the first instance, concentrates on the more basic mechanisms is likely to prove more efficient than one which examines a multiplicity of processes that could share a common origin.

Apart from genetic programming, the two most basic hypotheses to explain loss of cell viability are (i) a steady accumulation of somatic mutations and (ii) a progressive feedback of errors in the translation of genetic information from DNA into protein. Obviously, a breakdown in either the genetic information itself or in the means for its translation could be responsible for deterioration in any or all cellular functions. The somatic mutation theory (Szilard 1959; Curtis 1966; Burnet 1974) is supported by evidence of an increasing frequency of somatic mutations with age both in vitro (Fulder and Holliday 1975) and in vivo (Morley et al., in press). However, there are serious difficulties in reconciling the somatic mutation theory to available data on cellular ageing (Holliday and Kirkwood 1981). While it seems plausible that somatic mutations may play a role as the immediate cause of death, it is likely that they represent only part of a general breakdown in the fidelity of information transfer between macromolecules.

The error theory of ageing was originally proposed in the context only of a feedback of errors in protein synthesis (Medvedev 1962; Orgel 1963): Each set of the proteins involved in translation is responsible, among other things, for synthesising its successor, so errors can be propagated cyclically to the point where a lethal breakdown in fidelity occurs. However, the close linkage of the pathways of transcription, translation, replication, and repair of genetic information (Fig. 6) suggests that a more general error theory, which includes the possibility of error feedback at all levels of information transfer, is more plausible (Holliday and Tarrant 1972; Orgel 1973; Brash and Hart 1978; Kirkwood 1980). Evidence to support the hypothesis of a general accumulation of errors in human fibroblasts has been reported (Holliday and Tarrant 1972; Linn et al. 1976), but contrary results have also been claimed (Evans 1977; Harley et al. 1980). From theoretical studies of the error theory (Kirkwood 1980; Rosenberger and Kirkwood 1981) it appears that the predictions are more complex than was originally recognised, and it may be some time before relevance of the theory to ageing is unambiguously resolved.

\section{"Immortalisation" of Transformed Cells}

One question of great interest to cytogerontologists is why heteroploid transformed cells, unlike diploid cells, grow in-

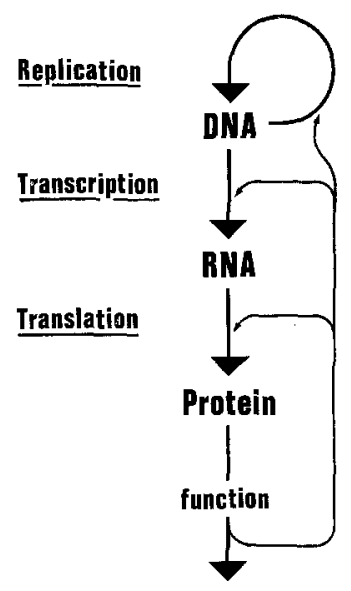

Fig. 6. The cyclic nature of the pathways of information transfer between macromolecules admits the possibility of a feedback of errors within a cell. The main sequence of information flow is from DNA to RNA to protein, and there is also the replication of DNA itself. However, specific proteins (enzymes) participate in each of these processes so that, for example, an erroneous protein molecule which retains some activity but loses normal specificity could generate a large number of new errors. In this way, errors might be propagated cyclically within the cell until it was no longer able to function 
definitely in culture. This question has obvious relevance to cancer research, and characterisation of the difference between "mortal" and "immortal" cultures is also likely to throw considerable light on the basic mechanisms of ageing.

We should note first that the change from mortality to immortality of a culture need not necessarily be a major qualitative change whereby each mortal cell becomes an immortal one. All that is necessary is that there should exist within the population a group of immortal cells which does not decrease in numbers from one subculture to the next (see Orgel 1973). In terms of the commitment theory, for example, a culture can be immortalised by a relatively small change in either the probability of a cell becoming committed, or in the number of cell generations which must elapse before a committed cell ceases to divide (Kirkwood and Holliday 1975). Evidence that a significant proportion of cells in cultures of the transformed HeLa cell line are, indeed, capable only of a limited number of divisions has been reported by Martinez et al. (1978).

Any theory to explain the mechanism of cellular ageing in normal cells must be complemented by a description of how this mechanism may be altered or inactivated so as to allow indefinite growth in transformed cells. In the case of a genetic programme, the explanation is easy: Mutation, or an epigenetic change in gene regulation (Holliday 1979), may simply interrupt the programme. Most carcinogens are, after all, potent mutagens. In the case of the error theory, two primary alternatives exist. The first is that cells are changed in such a way that selection against errorcommitted cells is intensified. This could happen either if the cell is released from its normal growth controls so as to multiply at maximum rate (which would then be critically dependent on the efficiency of translation) or if the build-up of errors occurs more rapidly (Holliday 1974; Kirkwood and Holliday 1975). The second possibility is that an epigenetic change in gene expression may reactivate special error-correcting mechanisms which normally operate only in the germ line, and which are switched off for energy-saving reasons in somatic cells (Kirkwood 1977). Such a change would render a cell less liable to become error committed and could be associated with the neoplastic reversion to a quasi-embryonic state which is so common in transformed cells. Finally, in the case of theories postulating an accumulation of cytoplasmic damage or toxic metabolic wastes, a minor change in the rate of cell division could make the crucial difference between accumulation and steady dilution of harmful elements (Sheldrake 1974; Hirsch 1978).

Studies involving the fusion of transformed cells to normal cells that have ceased to proliferate have shown that, in some cell lines (including $\mathrm{HeLa}$ ), the transformed phenotype appears to be dominant to the normal one (in the sense of stimulating reinitiation of DNA synthesis), while in others it is not (Stein and Yanishevsky 1979). Stein and Yanishevsky concluded that transformation is a heterogeneous phenomenon which can occur in more than one way. Specifically, they postulated that normal cells, which they assume are programmed to cease dividing, can become transformed to immortality either by losing a regulatory factor (so that in fusion with a normal cell the immortal phenotype is recessive) or by gaining a transformation factor (with the reverse effect of dominance). Later studies by Bunn and Tarrant (1980), who examined the replicative capacity of hybrids produced by fusion between Lesch-Nyhan limited lifespan fibroblasts and HeLa cells, showed that the apparent dominance of HeLa over the limited lifespan phenotype did not, in fact, normally extend to ensuring unlimited lifespan (the fused cells showed a frequency of appearance of indefinitely growing colonies of only about 1 in $2 \times 10^{5}$ ). However, the average lifespan of the hybrids was greater than that of the normal LeschNyhan cells. Bunn and Tarrant (1980) interpreted this last point as evidence against a rigidly programmed cessation of division in the Lesch-Nyhan cells.

Finally, in addition to systems for studying the numerous ways (e.g. by viruses, chemicals, radiation) in which normal limited lifespan cells can be transformed to apparent immortality, there exists one valuable system for studying the reverse of this process, namely the differentiation of teratocarcinoma cells into a wide variety of normal, non-malignant cells (Stevens 1967). The pluripotency of these neoplastic cells, which resemble undifferentiated embryonic cells in their structure and biochemistry and which, in mice at least, undergo normal differentiation to produce a chimeric animal when inserted into an early embryo, is now widely recognised as a valuable model for the study of embryogenesis and cell differentiation (Illmensee and Stevens 1979; Martin 1980).

In particular, careful examination of the changes which occur when a teratocarcinoma cell, which has an indefinite lifespan in culture, spontaneously generates cells which have only finite lifespans in culture (Topp et al. 1977) may help us to understand the mechanism by which mortal somatic cells are produced from an immortal germ line.

\section{Other Instances of Ageing}

The foregoing sections of this review have been concerned with the ageing of somatic tissue in higher animals. In this section, we consider briefly other instances of ageing and discuss how some of the evolutionary principles we have encountered may apply to them as well. A more detailed analysis of these points may be found elsewhere (Kirkwood 1981).

\section{Ageing in Species Which Reproduce Only Once}

A major distinction exists between species which reproduce repeatedly during their lifetime and those which reproduce only once (Cole 1954). In the latter, the act of reproduction signals the end of the life cycle, and death usually occurs soon after. In some instances, death and reproduction are so intimately linked that the latter directly involves the former, as in the mite Adactylidium where the young hatch inside the body of the mother and literally eat their way out. Organisms which exhibit "once only", or semelparous, reproduction include the Pacific salmon, octopus, many lower invertebrates, and annual and biennial plants.

For a semelparous organism, the Medawar-Williams argument of a declining force of natural selection with age does not apply. This is because selection continues to operate with full force until reproduction begins. Once reproduction is complete the force of selection is reduced to zero unless the adult plays an active part in promoting survival of the young. Thus, for semelparous species, the pattern of selection corresponds exactly with that envisaged more generally by Weismann, and his panmixia argument directly applies ${ }^{6}$. In terms of the disposable soma theory, a semelparous organism which has embarked on the reproductive phase of its life cycle should mobilize all its

6 In fact, Weismann specifically considered the relevance of his theory to semelparous life histories in the particular context of Lepidoptera species in which adults lack a functional mouth (Weismann $1892 \mathrm{a}$, pp. 51,187). He noted that such loss may occur both as a result of panmixia and of extreme adaptation to the rapid deposition of eggs at a single time 
resources to maximising its reproductive effort, even if this means neglecting maintenance of the soma to such an extent that it is condemned to early post-reproductive death. As noted already, the only exceptions to this general rule will be when some form of parental care is practised.

In summary, in semelparous species the lifespan is under strict genetic control until reproduction occurs. Thereafter, the organism may either destroy itself, decay fairly rapidly, or persist for a while according to the details of its ecological and behavioural niche. Ageing in such organisms is therefore very different from ageing in repeatedly reproducing, or iteroparous, species in which the life-span could, in principle, extend indefinitely.

\section{Ageing Where There Is No Clear Distinction Between Soma and Germ Line}

In the great majority of plant species and in many invertebrates there is no clear separation of the soma from the germ line, such as is found in higher animals. Almost any part of the organism may be capable of regenerating a new one by vegetative growth, given a suitable environment. In such species, neither Weismann's argument for evolution of cellular ageing nor the disposable soma theory is directly valid (for relevant discussion by Weismann, see Appendix 2). However, the general principle of optimising the balance between repair and other activities still applies, and there may be instances in which the best strategy does not necessarily ensure indefinite survival of all parts of the organism (see Kirkwood 1981). A case in point is the asexual division of some species of turbellarian worms into anterior and posterior halves. Each half usually regenerates a whole worm, but only the posterior halves can continue to do so indefinitely (Sonneborn 1930). The failure of the anterior halves to propagate themselves without limit may be a consequence of insufficient repair of major organs such as the brain (Calow 1978).

\section{Ageing of Unicellular Organisms}

It has been found that certain commonly investigated protozoan species undergo clonal senescence unless periodic sexual crossing occurs (see, for example, Sonneborn 1954). At first sight such a finding seems surprising, since for a unicellular organism the soma and germ line are essentially one and the same, and the germ line must be immortal. It is interesting, therefore, that Weismann himself was well aware of the work of Maupas, who first described that colonies of Paramecium caudatum which have passed the proper time for conjugation gradually die out (Weismann 1892b, pp. 201-210; 1913a, pp. 270-273; see also Appendix 2). In Weismann's view such clonal senescence was unlikely to be itself adaptive but was instead a side effect of adaptation to conjugation. The high selective advantage of conjugation in bringing about "amphimixia", a term by which Weismann described genetic recombination, rendered it possible, he suggested, that clonal senescence takes place in those animals which are prevented from undergoing conjugation as a "consequence of the necessary internal changes which [would normally] lead to conjugation".

Attempts to establish the biological significance of clonal senescence in protozoans and of the rejuvenating effects of conjugation have occupied a considerable amount of protozoologists' time (for reviews see Child 1915 and Sonneborn 1954) and as yet are still incomplete. One possibility, suggested by work of Smith-Sonneborn (1979) on Paramecium tetraurelia, is that in certain protozoan species, sex serves as a genetic repair mechanism of considerable importance. In Smith-Sonneborn's experiments, activation of an inducible DNA repair system (photoreactivation of pyrimidine dimers) resulted in an increase in the number of divisions before death. This suggests that damage to DNA plays a part in limiting the replication of the cells and, therefore, that sex, which rejuvenates the cells, can overcome this damage. If this is the case, strains in which sex is not used, or is used only rarely, must possess alternative repair systems to allow clones to grow indefinitely.

\section{Ageing in Germ Cells}

Although the germ line must, in a certain sense, be immortal, it is well known that individual germ cells deteriorate with age (for a recent review, see Medvedev 1981). In particular, there is welldocumented evidence of both maternal and paternal age effects in the frequency of genetic abnormalities in human offspring (Vogel and Rathenberg 1975; Kram and Schneider 1978).

That age-related changes occur in germ cells is not particularly surprising, nor is it inconsistent with theories of somatic ageing which distinguish between germ cells and somatic cells. The increase in abnormal progeny, especially with maternal age, may reflect either less efficient screening for faults as a general consequence of senescence, or it may be due to the weakness of selection for late reproductive viability (by the MedawarWilliams argument). Over a time-scale of generations, however, damage must not be allowed to accumulate in the germ line, and this may be prevented by any of several mechanisms. Firstly, there may exist within germ cells special repair mechanisms to prevent accumulation of damage. Secondly, meiosis and recombination can serve to eliminate genetic faults. Thirdly, failure of implantation of the fertilised ovum or spontaneous abortion of abnormal foetuses may prevent many potential defects from being realised in the progeny. None of these mechanisms is, of course, completely error-free, or mutation and evolutionary change would not be possible. The final errorcorrecting process for mistakes which pass through these screens is phenotypic selection among the viable progeny.

In addition to changes in germ cells associated with age of the organism, there is evidence, also reviewed by Medvedev (1981), that both male and female gametes deteriorate quite rapidly if they fail to achieve fertilisation. In the spermatozoan the reason for this is obvious in that the cell is so highly specialised for its task of finding and fusing with the ovum that it lacks many of the normal cytoplasmic constituents required for extended independent existence. Weismann early recognised this fact and took care to point out that the death of gametes which fail in their primary function did not invalidate the concept of immortality of the germ line, but simply indicated the lack of any selective advantage in their living longer (Weismann 1891, pp. 203-204).

\section{Weismann Reappraised}

From our re-examination of Weismann's theory and our review of subsequent research, two points emerge. The first is that Weismann's insight into the problem of ageing was considerably more profound than is generally realised today. The second is that most of the substantive points of this theory have been independently resurrected at later dates. It is thus natural to ask why cytogerontology has followed this tortuous path and 
whether we might be further advanced in our knowledge if it had not.

Without doubt, a crucial influence on the course of research on cellular ageing was the work of Carrel and Ebeling. Had they not committed themselves so firmly to the idea that somatic cells do not age and worked so assiduously to sustain this view, it seems likely that tissue culture systems for examining the validity of Weismann's predictions would have been developed much earlier. If this had been the case, it is probable that we would now know considerably more about ageing in different types of somatic cells and about the relationship between cellular and whole animal ageing than we do. These questions have been considered in depth only during the two decades which have elapsed after Hayflick and Moorhead's experiments reopened speculation about a cellular basis for ageing.

As far as research on basic mechanisms of ageing is concerned, it is less likely that progress would have occurred significantly faster if Weismann's ideas had been followed up. This research would still have had to await the birth and development of molecular biology, since most of the theories which are the subject of serious research today derive from concepts and techniques which have only become available comparatively recently. Nevertheless, it is probable that, had research at the cellular level already progressed further, model systems for molecular biological studies would by now be better defined. As it is, the development and validation of these models is occurring concurrently with their use in probing the molecular mechanisms of cellular ageing. This has obvious disadvantages.

With a few rare exceptions (e.g. Strehler 1977), the only component of Weismann's theory which is quoted today is his early adaptive argument that ageing evolved as a means of eliminating old and worn-out individuals which are useless to the species. This is most probably due to the heavily critical account of Weismann's theory by Medawar (1952). While Medawar's attack on specific points of confusion in Weismann's argument was well founded, he was referring only to a minor part of the theory, and Medawar seems to have been unaware that in Weismann's later essays he changed his emphasis to a non-adaptive view and, to a significant extent, anticipated Medawar's own hypothesis. As we have previously noted, Weismann may himself have contributed to this situation through his policy of republishing outmoded essays with only a non-specific cautionary note in his preface that the individual essays should not be taken as a full and complete statement of his view.

In this connection, misunderstanding of Weismann's theory has probably been compounded by one particularly unfortunate sentence, quoted by Medawar (1952) and later repeated by others (e.g. Comfort 1979): "Death takes place because a worn-out tissue cannot for ever renew itself". When read in context (see Section 2), it is clear that Weismann did not intend this sentence to have the circular meaning which seems so obvious when it is read by itself. Some circularity certainly can be found in Weismann's adaptive explanation for the evolution of ageing, but this was a different point.

Looking over the total spread of Weismann's work on ageing, we found it truly remarkable how extensively he sowed intellectual seeds which, given the right conditions, might have flourished into important components of the research of ageing today. The factors we have identified as contributing to the present incomplete awareness of his work may be summarised as follows. Firstly, the technical means for testing his theory did not exist at the relevant time, and he himself was hindered by worsening eyesight from attempting to develop them. Secondly, when means did become available in the early part of this century, the results were contrary to his prediction. Thirdly, his evolutionary arguments were discredited by Medawar's criticism. A possible fourth factor of unknown significance is that very shortly after Carrel and Ebeling first published their results, and in the final year of Weismann's life, world war broke out. Weismann, an ardent nationalist, formally renounced the scientific honours which had been bestowed on him by Germany's enemies, and thus possibly alienated his work from non-German scientists.

\section{Lessons for the Future}

Our main purpose in writing this review has been to analyse the direction which cytogerontology has taken in the past, with a view to deriving lessons for future strategies of research. The questions which emerge as being of primary importance are the following:

i) To what extent does somatic cell ageing really take place in the various histological compartments of the body? Some cells obviously last longer than others (compare neurones with red blood cells), and some (e.g. stem cells) may not age at all. Clearly it is of paramount importance to resolve this issue and to define appropriate experimental models for in vivo and in vitro research. Without this information, any results that are obtained will be dogged by the uncertainty of their true relevance to ageing as it occurs naturally. For some systems, particularly fibroblast tissue culture, considerable information is already available, but even for these there remain important doubts which have yet to be settled.

ii) Do somatic cells accumulate damage as the organism ages? If somatic cell ageing is a genuine phenomenon, the disposable soma theory predicts that somatic cells should accumulate increasing amounts of damage during the course of an organism's life. A few preliminary studies have been made which bear on this question (see Section 4), but clearly it needs to be studied more comprehensively than has been done so far.

iii) What somatic repair systems are primarily responsible for regulating the duration of cellular and organismic lifespans? This question, which complements the previous one, strikes at the fundamental basis of ageing. The most promising current lines of attack are comparative analysis of the efficiency of somatic repair systems in different species and genotypes which have differing longevity. Progress with the interspecies approach owes much to pioneering work by the late George A. Sacher (to whom we have dedicated this review), while considerable advances may also result from the study of segmental progeroid syndromes (e.g. Werner's syndrome) in man (Martin 1979).

iv) What is responsible for the transition from a potentially immortal germ line to a limited lifespan somatic cell, and for the reverse transition that occurs during neoplastic transformation? Are these two processes related in any way? As we have already mentioned, one potentially very valuable system for study of these questions is the differentiation of teratocarcinoma cells into quasi-normal limited lifespan somatic cells. Also of interest is to establish what precisely is the cell kinetic basis of the difference between a cell population capable of indefinite growth and one capable 
only of finite growth. For instance, to what exact extent is "immortalisation" of a cell population, as measured in terms of its growth potential in vitro, associated with transformation to malignancy.

A theme which we particularly wish to emphasise as relevant to ageing research is the perspective offered by evolutionary considerations. Weismann saw clearly the importance of bringing the theory of natural selection to bear on questions of cellular ageing. This theme was largely abandoned during the five decades when Carrel's view reigned supreme, but has now been taken up again in the form of the disposable soma theory. No doubt there are important advances yet to be made in the theoretical analysis of evolution of ageing, and the critical experimental tests have yet to be conducted. Nevertheless, we believe that the current evolutionary paradigm has much to offer. In particular, the strength of the argument against adaptive explanations of ageing seems to us to speak very strongly against the usefulness of programme theories of ageing.

Finally, we wish to stress the need to take account of an organism's life-history when considering what is meant by the term "ageing". The post-reproductive life of a semelparous organism is, for example, very different from the later part of an iteroparous lifespan, and this is different again from the old age of a vegetatively reproducing plant or invertebrate. In fact, "ageing" is used with so many different meanings in so many different contexts that it is sometimes highly confusing when used without proper qualification. If the disposable soma theory proves to be correct, the identification of senescence with the accumulation of damage offers the possibility to consider many different types of failure of life maintenance more precisely within a single broad conceptual framework (Kirkwood 1981).

Acknowledgements. We are indebted to the following for reading drafts of this review and for making a number of very helpful comments: Drs. I. D. J. Burdett, H. Höhn, R. Holliday, G. M. Martin, Zh. A. Medvedev, H.G. Schwarzacher, F. Vogel, R.Zwilling. We also thank Oxford University Press and Macmillan Journals Ltd, publishers of Nature, for their kind permission to reprint material from Weismann's works. The gift of a copy of Weismann's work “Aufsätze über Vererbung und verwandte biologische Fragen" from Dr. Winfried Grassmann to T.C. is gratefully acknowledged. Janice Markham gave excellent assistance in preparing the typescript.

\section{Appendix 1}

\section{Adaptivity, Non-adaptivity, and Programmed Ageing and Death}

It is apparent both from the literature and from a number of discussions that there is some confusion over the precise meaning of terms such as "adaptive" or "programme" in the context of theories on ageing. In this appendix we therefore define these terms carefully in the sense we use them in our review, a sense which seems to us the correct one.

An adaptive theory of ageing is one in which the process of senescence is regarded as conferring by itself a selective advantage on the genotype which produces it. Thus, an adaptive theory must suggest a reason why, other things being equal, an organism which ages is fitter in a neoDarwinian sense than one which does not. Conversely, a non-adaptive theory takes the opposite view, that senescence is itself detrimental to fitness, or at best selectively neutral. Non-adaptive theories therefore have to explain the evolution of ageing indirectly. The two main kinds of non-adaptive theory (see Section 3) are that (a) the force of natural selection declines with age and is eventually too weak to prevent senescence, or (b) senescence is a by-product of other adaptive traits.

It is the second kind of non-adaptive theory which generates most confusion, as can be illustrated in the context of the disposable soma theory of ageing (see Section 3). The disposable soma theory asserts that senescence is the result of channelling fewer resources into somatic maintenance and repair than are required to sustain the soma indefinitely and of investing the resources which are thereby saved into greater reproductive effort. Thus, although the soma is condemned to a finite duration of life, its reproductive fitness is enhanced. Confusion appears to arise as to whether this is an adaptive or non-adaptive theory of ageing because senescence is proposed to be the direct outcome of positive selection for the optimal allocation of metabolic resources. The crucial point, however, is that there is nothing in the theory which suggests that senescence is itself advantageous. Quite the reverse is, in fact, true. The theory regards senescence as disadvantageous and is concerned with the role of natural selection in balancing the advantage of extending the duration of life through better somatic repair against the competing advantage of increasing the investment in progeny. Thus, we regard as incorrect the view of Guthrie (1969), who in setting forth an argument similar to that of the disposable soma theory, described ageing as an adaptive trait.

A second, related source of confusion is the use of the word programme in connection with ageing. We choose in our review to restrict the term "programmed ageing" to processes which are programmed in the same strict sense as development, namely a specific sequence of events occurring under direct genetic control. Programmed ageing is thus most appropriately considered in the context of adaptive theories which suggest positive selection for a controlled termination of life. If ageing is assumed to have evolved in a non-adaptive way, there seems no reason to suppose that such a well-defined programme would exist. This is not say, however, that non-adaptive ageing would not be genetically determined. In fact, it is obvious both from interspecies comparisons and from studies on inbred strains of laboratory animals that duration of life is dependent on genotype. Thus, the issue that distinguishes programmed from nonprogrammed ageing is not whether the factors that determine longevity are specified within the genome, but rather, how this is arranged. An organism which undergoes programmed ageing is regarded as having a specific mechanism to limit its duration of life, whereas an organism which is not programmed in this way does not. In the latter type of organism, duration of life may be determined, for example, simply by the efficiency of somatic repair. It might be argued that the restrictions we place on the use of the term "programmed" are arbitrary, semantic ones, and there is of course some truth in this view. Nevertheless, we feel that the above distinction is a useful one and that the difference between these two types of genetic control of longevity needs to be emphasised.

Finally, a context in which the term "programmed ageing" is frequently, but we think questionably, used is in the post-reproductive death of semelparous (i.e. reproducing once only) species (see Section 5). Here it is not the programming which is in question, but the validity of the word ageing to describe what is often a specific shut down of life (see also Sacher 1978). In semelparous reproduction, the organism has only one chance of procreation, and natural selection will therefore have favoured any process which boosts the likelihood of success, even if such a process is suicidal to the post-reproductive adult. In some cases death of the parent may actually benefit the young directly, for example by providing a source of food. In these cases it is better to talk of programmed death, rather than ageing, the organism remaining under strict genetic control throughout the cycle from birth to death. Programmed death in semelparous species is analogous to adaptive or programmed ageing in iteroparous (i.e. reproducing repeatedly) species. On the other hand, it may be the case that post-reproductive death in a semelparous organism is not directly of benefit to the progeny, but is merely the consequence of massive depletion of vital resources or of damage caused by the intensity of the reproductive effort. In such instances it is not the deterioration and death of the post-reproductive adult which is programmed, but the events associated with the act of reproduction. This kind of deterioration, whether or not one chooses to call it ageing, is analogous to non-adaptive ageing in iteroparous species since it too is either a failure of adequate selection for survival or a byproduct of something else. In general, when discussing these matters, we think it is most important to bear in mind that duration of life in semelparous species is regulated in a way that is qualitatively quite different from that which applies in iteroparous species.

\section{Appendix 2}

In his writings, Weismann organised a very wide range of biological subjects within the general framework of his theory of heredity. In doing 
so, he adhered consistently to two basic principles, namely a strictly antivitalistic view of life and a firm rejection of Lamarckism. His ideas provoked a wealth of debate among the scientific community, and much criticism was directed against his theory by those who preferred to imagine a non-material component in living matter or who favoured the transmission of acquired characters. A large part of this debate took place in the form of correspondence to Nature [see volumes 39-41; a list of published criticism of Weismann's theory may also be found on pp. xiii-xv of Weismann (1891)]. We have chosen, therefore, to complement our review of Weismann's theory of ageing by reprinting as an appendix an article by Weismann which appeared in Nature in 1890 (41:317-323).

In this article, Weismann was chiefly responding to criticism of his theory by Vines. However, in the course of his reply to points mainly concerned with cellular ageing, Weismann alluded to several of the broader aspects of his research. His article therefore serves as an excellent illustration both of his own personal scientific style and of the contemporary state of cell biology at a time ten years before Mendel's laws were rediscovered. The reader may observe that many of the points which Weismann was pressing forward are now so deeply ingrained in our view of biology that it is easy to forget that they were once such novel and contentious issues.

"In NATURE of October 24,1889 (p. 621), appeared a criticism by Prof. Vines of my essays on heredity and allied subjects. I should be glad to reply briefly to his objections, and the more so as I hope thus to be able to place the scientific problems at issue in a somewhat clearer light. With regard to the immortality which I attribute both to the unicellular organisms and to the germinal cells of the multicellular, if I understand Prof.Vines aright, he does not attack the proposition itself, but has simply overlooked the explanation in my book of the way in which mortal organisms arose out of immortal in process of phyletic development, a process which must have taken place if the Protozoa have developed in the course of the world's history into the higher Metazoa,"the first difficulty is to understand how the mortal heteroplastides can have been evolved from the immortal monoplastides." My explanation was simply that which appears to be the true one for the origin of every higher differentiation-namely, the division of the cell-mass of the Protozoan, on the principle of the division of labour, into two dissimilar halves, differing in substance, and consequently also in function; from the one cell which performed all functions comes a group of several cells which distribute themselves over the work. In my opinion, the first such differentiation produced two sets of cells, the one the mortal cells of the body proper, the other the immortal germ-cells. Prof. Vines certainly believes in the principle of the division of labour, and in the part that it has played in the development of the organic world, as well as I; but it seems to him that this division of a unicellular being into somatic and germinal cells is impossible, and that my explanation of the process by dissimilar division is inadequate, because it strikes him as "absurd to say that an immortal substance can be converted into a mortal substance."

There certainly does seem to be a great difficulty in this idea, but in reality it arises simply from a confusion of two conceptions-immortality and eternity. That the Protozoa and the germ-cells of Metazoa are in a certain sense immortal seems to me an incontrovertible proposition. As soon as one has clearly realized that the division of a monoplastid is in no way connected with the death of one part, there can be no further question that we have to do with individuals of indefinite duration; but this in no way implies that they possess an eternal duration; on the contrary, we imagine that they have all had a beginning. The conception of eternity, however, extends into the past as well as the future; it is without beginning or end, and does not affect the present question; it is an entirely artificial conception, and has no real and comprehensible existence; to express it more accurately, eternity is merely the negation of the conception of transitoriness. Of the objects with which natural science deals, none are eternal except the smallest particles of matter and their forces, certainly not the thousandfold semblances and combinations under which matter and force meet us. As I have said years ago, the immortality of unicellular organisms, and of the germ-cells of the multicellular, is not absolute but potential; it is not that they must live for ever as did the gods of the ancient Greeks - Areas received a "mortal" wound, and roared for pain like to ten thousand bulls, but could not die; they can die-the greater number do in fact die-but a proportion lives on which is of one and the same substance with the others. Does not life, here as elsewhere, depend on metabolism - that is to say, a constant change of material? And what is it, then, which is immortal? Clearly not the substance, but only a definite form of activity. The protoplasm of the unicellular animals is of such chemical and molecular structure that the cycle of material which constitutes life returns even to the same point and can always begin anew, so long as the necessary external conditions are forthcoming. It is like the circulation of water, which evaporates, gathers into clouds, and falls as rain upon the earth, always to evaporate afresh. And as in the physical and chemical properties of water there is no inherent cause for the cessation of this cycle, so there is no clear reason in the physical condition of unicellular organisms why the cycle of life, i.e. of division, growth by assimilation, and repeated division, should ever end; and this characteristic it is which I have termed immortality. It is the only true immortality to be found in Nature-a pure biological conception, and one to be carefully distinguished from the eternity of dead, that is to say unorganized, matter.

If then this true immortality is but cyclical, and is conditioned by the physical constitution of the protoplasm, why is it inconceivable that this constitution should be, under certain circumstances and to a certain extent, so modified that the metabolic activity no longer exactly follows its own orbit, but after more or fewer revolutions comes to a standstill and results in death? All living matter is variable; why should not variations in the protoplasm have also occurred which, while they fulfilled certain functions of the individual economy better, caused a metabolism which did not exactly repeat itself, i.e. sooner or later came to a condition of rest? I admit that I feel such a descent from immortality into mortality far less remarkable than the permanent retention of immortality by the monoplastids and germ-cells. Small, indeed, must be the variations in the complicated qualities of living matter to bring in their train such a fall; and very sharply must the essentials of its constitution be retained, for metabolism to take place so smoothly without creating in itself an obstacle to its own continuance! Even if we cannot penetrate into the mysteries of this constitution, still we may say that a rigorous and unceasing natural selection is unremittingly active in maintaining it at such an exact standard as to preserve its immortality; and every lapse from this standard is punished by death.

I believe that I have proved that organs no longer in use become rudimentary, and must finally disappear solely by "panmixie"; not through the direct action of disuse, but because natural selection no longer maintains their standard structure. What is true for an organ is true also for its function, since the latter is but the expression of the qualities of material parts, whether we can directly perceive their relations or not. If, then, as we saw, the immortality of monoplastids depends on the fact that the incessant metabolism of their bodies is ever returning exactly to its starting-point, and produces no such modifications as would gradually obstruct the repetition of the cycle, why should that quality of the living matter which causes immortality-nay, how could it be retained - when no longer necessary? It is obvious that it was no longer necessary in the somatic cells of the heteroplastids. From the instant that natural selection relaxed its watch on this quality of immortality began the process of panmixia which led to its abolition. Prof. Vines will ask, How can one conceive of this process? I answer, Quite easily. When once individuals arose among monoplastids, in the protoplasm of which occurred such variation in chemical and molecular constitution as to result in a gradual check on the metabolic cycle, it would happen that these individuals died; a permanent variety could not grow out of such variations. But if there arose among heteroplastids individuals with a similar differentiation of the somatic cells, the death of these cells would not be detrimental to the species, since its continuance is ensured by the immortal germ-cells. Upon the differentiation into germinal and somatic cells, natural selection was, speaking metaphorically, trained to bear on immortality of the germ-cells, but on quite other qualities in the somatic cells - on motility, irritability, capacity for assimilation, \&c. We do not know whether the attainment of these qualities was accompanied by a constitutional alteration which caused the loss of immortality, but it is at least possible; and, if true, the somatic cells will have lost their immortality even more rapidly than through the unaided action of panmixia.

In the fourth essay of my book, I have cited the two Volvocinean genera Pandorina and Volvox as examples of the differentiation of homoplastids into the lowest heteroplastids; in Pandorina the cells are 
still all alike and all perform the same functions, in Volvox occur somatic and germinal cells, and in the latter case we should expect to find the commencement of natural death. Recent researches of Dr. Klein ("Morphologische und biologische Studien über die Gattung Volvox," Jahrb. wiss. Botan., xx., 1889) show that this is actually the case; as soon as the germ-cells are ripe and emerge from the sphere, the ciliated somatic cells begin to shrivel up, and die in one or two days. This is the more interesting, as the somatic are also the nutritive cells; for, though the germ-cells also possess chlorophyll, the rapid growth of the latter (which attain an enormous size in Volvox) is only possible by the supply of nourishment from the somatic cells. The latter are so constituted that they assimilate, but cannot grow larger when once the sphere has reached its definite size; they transfer the nourishment which they derive from the decomposition of carbon dioxide, \&c., to the germinal cells by means of fine pseudopodia; and themselves wither when once the germs are ripe. In this case adaptation to the nutrition of the germinal cells might well have accelerated the introduction of a natural death of the somatic cells, the capacity for considerable assimilation combined with a drain on their nutrition may have led after a certain time to stoppage of the process of assimilation and to death. To me, the idea that modification of the living matter may have been connected with loss of immortality does not appear more unlikely or more difficult than the generally received view of the gradual differentiation of the somatic cells in the course of phylogeny into their various species of digestive, secretive, motile, and nervous cells. An immortal unalterable living substance does not exist, but only immortal forms of activity of organized matter.

I maintain, therefore, in its entirety, my original statement, that monoplastids and the germ-cells of higher forms have no natural death. I do not know how this can to-day be better expressed than by saying that these living units possess a real and actual immortality as against the imaginary ideal immortality of the Greek gods. If death from internal causes does not exist for them, one may yet say with certainty that the fatal hour will one day strike for them all, not from internal causes, but because the external conditions for the constant renewal of vital activity will some day cease. The physicists prophesy that the circulation of water on the globe will end, not from any alteration in the qualities of water, but because external conditions will render this form of motion of aqueous particles impossible.

Prof. Vines then attacks my view of embryogeny. He finds it "not a little remarkable that Prof. Weismann should not have offered any suggestion as to the conception which he has formed of the mode in which the conversion of germ-plasm into somatoplasm can take place, considering that this assumption is the key to his whole position." He sees here the same difficulty as in the phyletic development, and says: "There is really no other criticism to be made on an unsupported assumption such as this, than to say that it involves a contradiction in terms." He means by this that the eternal cannot pass into the finite, as must be the case if the immortal germ-cell grow into the mortal soma. At the bottom of this objection lies the same confusion between immortality and eternity which has already been made clear. I do not wish to reproach Prof.Vines with this obscurity, as I felt the same objection myself for many years, and could not at once discover the reply to it; on the contrary, I am indebted to him for the opportunity to express myself on the point. Up to this time we have had no scientific conception of immortality; if this can be accepted, the significance of immortality is not life without beginning or end, but life which, after its first commencement, can continue indefinitely with or without modification (specific changes in the germ-plasm or the monoplastids); it is a cyclical activity of organic material devoid of any intrinsic momentum which would lead to its cessation, just as the motion of the planets contains no intrinsic momentum which would lead to its cessation, although it has had a commencement and will some day, through the operation of extrinsic forces, have an end.

Prof. Vines says later: "I understand Prof. Weismann to imply that this theory of heredity is not-like, for instance, Darwin's theory of pangenesis - a provisional or purely formal solution of the question, but one which is applicable to every detail of embryogeny, as well as to the more general phenomena of heredity and variation." I have, as a matter of fact, designated Darwin's pangenesis as a "purely formal" solution of the question, but should like here to give a slight explanation of the expression, as I fear that not only Prof. Vines, but also many other readers of my essays, have misunderstood me. On the one hand, I am afraid that they see in my words a definite reproach against Darwin for his theory of pangenesis, of which I had not the remotest intention; and on the other, that they incline to charge me with too great an affection for my own theory.

I believe there are two kinds of theory; one may term them the "real" and the "ideal"; practically they are rarely sharply to be discriminated; both often occur in one and the same theory, but should be conceived of separately. The "ideal" theories attempt to render conceivable the phenomena to be explained by an arbitrarily accepted principle, apart from the question whether the principle itself possesses any grain of truth or not; they seek only to show that there are hypotheses on which the phenomena in question become comprehensible. "Real" theories do not make hypotheses at pleasure, but strive to construct such as have some degree of propability; they desire to give not a formal, but, if possible, the right explanation. Sir William Thomson in endeavouring to make clear the dispersion of rays of light by conceiving of a molecule as consisting of hollow spheres enclosed one within the other and in contact with one another through springs, never believed in the remotest degree that such molecules as he pictured really existed, but desired merely to show that there were hypotheses on which the phenomena of dispersion were comprehensible. Darwin's pangenesis was originally intended in this sense, and was by him termed a "provisional" hypothesis, although in later years he may have attributed to it the weight of a real theory. To me his "gemmules" are a pure invention, an invention in no way corresponding to the actual facts, but showing what hypotheses must be made in order to explain the phenomena of heredity. Are, however, such ideal theories worthless? Certainly not. They are often the first and essential step towards the understanding of complicated phenomena, and lay the foundation for the gradual erection of a real theory. It would perhaps never have occurred to me to deny the inheritance of acquired characters, had not Darwin's pangenesis shown me that the matter was only explicable on an hypothesis so difficult to conceive, as that of the giving off, circulation, and reassemblage of gemmules. I do not even now maintain that Darwin's pangenesis cannot possibly contain a kernel of truth; De Vries ("Intracellulare Pangenesis," Jena, 1889) has shown in a recent and most interesting memoir that the ideal impossible pangenesis may be transformed into a real and possible one by means of certain profound modifications; he accepts my view that acquired (somatogenic) modifications cannot be transmitted, and thereby puts on one side just that part of Darwin's theory which has always appeared to me to lie beyond the pale of reality-namely, the circulation, \&c., of the gemmules. The future will show whether his view of modified gemmules or my hypothesis is the best explanation of the facts of heredity.

In any case, I am far from assuming that I have settled the whole question of heredity; I have undertaken researches on some of the more important parts of the problem, and have thus been compelled to formulate some fundamental principles for the explanation of the phenomena; but no one can be more convinced than I how far we are from a definite and complete explanation, not only of "every detail," but also of "the more general phenomena." My endeavour was to put forth a real, in place of the previous ideal, theory; and on this ground I took pains to make only such suppositions as might possibly correspond to actual facts. There certainly is a material carrier of hereditary in the ovum; it certainly can be transported from nucleus to nucleus; it certainly can be modified in the process, or can remain the same; and even the supposition that it is able to stamp its own character on the cell contains nothing which seems to us impossible and non-existent; on the contrary, we are able now to state that it is so, even if we do not understand in what wise it happens. My hypothesis relative to the quiescent state of germplasma also rests on a basis of fact; we know that ancestral characteristics may be transmitted in a latent condition, and that the process of transmission is bound up with a substance, the idioplasma; there must therefore actually be an inactive stage of idioplasma.

If it could be shown that upon such principles explanation of heredity is attainable, we should have made a distinct advance upon the ideal theory of pangenesis which is founded on unreal hypotheses. Possibly it is upon the path which I have opened up that we shall gradually attain a satisfactory solution of the numerous questions at issue; possibly further research will show that it is not the right path, and must be abandoned; no one, it appears to me, can foretell this. My reflections on heredity are not a conclusion, but a commencement-no complete theory of heredity 
which claims to provide a complete solution of all the problems at issue, but researches which, if fortunate, may sooner or later, by direct or circuitous paths, lead to a true appreciation of the question, to a "real" theory. In the preface to the English edition of my "Essays" I have stated this expressly.

I have also in that place distinctly insisted that the book was not written as a whole; that it consists rather of a series of researches, the one growing out of the other, and showing the development of my views as they shaped themselves during the course of nearly a decade's work. It is therefore unreasonable to extract ideas from an earlier essay and apply them against a later one. I have left them unaltered, and even "left certain errors of interpretation uncorrected," because, if altered, their internal connection could not have been understood.

I believe that the objections which Prof. Vines makes to my theory of the continuity of germ-plasma rest solely on an unintentional confusion of my ideas, as he compares the opinions expressed in the second essay with those of the later ones, with which they do not tally. I will endeavour to make this clear. In this second essay (1883) I contrasted the body (soma) with the germ-cells, and explained heredity by the hypothesis of a "Vererbungs-substanz" in the germ cells (in fact the germ-plasma), which is transmitted without breach of continuity from one generation to the next. I was not then aware that this lay only in the nucleus of the ovum, and could therefore contrast the entire substance of the ovum with the substance of the body-cells, and term the latter "somatoplasm." In Essay IV. (1885) I had arrived, like Strasburger and O. Hertwig, at the conviction that the nuclear substance, the chromatin of the nuclear loops, was the carrier of heredity, and that the body of the cell was nutritive but not formative. Like the investigators just named, I transferred the conception of idioplasma, which Nägeli had enunciated in essentially different terms, to the "Vererbungs-substanz" of the ovumnucleus, and laid down that the nuclear chromatin was the idioplasma not only of the ovum but of every cell, that it was the dominant cellelement which impressed its specific character upon the originally indifferent cell-mass. From then onwards, I no longer designated the cells of the body simply as "somatoplasm," but distinguished, on the one hand, the idioplasm or "Anlagen-plasma" of the nucleus from the cellbody or "Cytoplasma," and, on the other, the idioplasm of the ovumnucleus from that of the somatic cell-nucleus; I also for the future applied "germ-plasm" to the nuclear idioplasm of ovum and spermatozoon, and "somatic idioplasm" to that of the body-cells (e.g. p. 184). The embryogenesis rests, according to my idea, on alterations in the nuclear idioplasma of the ovum, or "germ-plasm"; on p. 186, et seqq., is pictured the way in which the nuclear idioplasm is halved in the first celldivision, undergoing regular alterations of its substance in such a way that neither half contains all the hereditary tendencies, but the one daughter-nucleus has those of the ectoblast, the other those of the entoblast; the whole remaining embryogenesis rests on a continuation of this process of regular alterations of the idioplasma. Each fresh celldivision sorts out tendencies which were mixed in the nucleus of the mother-cell, until the complete mass of embryonic cells is formed, each with a nuclear idioplasm which stamps its specific histological character on the cell.

I really do not understand how Prof. Vines can find such remarkable difficulties in this idea. The appearance of the sexual cells generally occurs late in the embryogeny; in order, then, to preserve the continuity of germ-plasm from one generation to the next, I propound the hypothesis that in segmentation it is not all the germ-plasm (i.e. idioplasm of the first ontogenetic grade) which is transformed into the second grade, but that a minute portion remains unaltered in one of the daughter-cells, mingled with its nuclear idioplasm, but in an inactive state; and that it traverses in this manner a longer or shorter series of cells, till, reaching those cells on which it stamps the character of germinal cells, it at last assumes the active state. This hypothesis is not purely gratuitous, but is supported by observations, notably by the remarkable wandering of the germinal cells of Hydroids from their original positions.

But let us neglect the probability of my hypothesis, and consider merely its logical accuracy. Prof. Vines says:-"The fate of the germplasm of the fertilized ovum is, according to Prof. Weismann, to be converted in part into the somatoplasm [!] of the embryo, and in part to be stored up in the germ-cells of the embryo. This being so, how are we to conceive that the germ-plasm of the ovum can impress upon the somato- plasm [!] of the developing embryo the hereditary character of which it (the germ-plasm) is the bearer? This function cannot be discharged by that portion of the germ-plasm of the ovum which has become converted into the somatoplasm [!] of the embryo for the simple reason that it has ceased to be germ-plasm, and must therefore have lost the properties characteristic of that substance. Neither can it be discharged by that portion of the germ-plasm of the ovum which is aggregated in the germcells of the embryo, for under these circumstances, it is withdrawn from all direct relation with the developing somatic cells. The question remains without an answer." I believe myself to have answered this above. I do not recognize the somatoplasm of Prof. Vines; my germplasm or idioplasm of the first ontogenetic grade is not modified into the somatoplasm of Prof. Vines, but into idioplasm of the second, third, fourth, hundredth, \&c., grade, and every one impresses its character on the cell containing it.

Prof. Vines also attacks my view of the idioplasmatic nature of the nuclear substance (the chromatic grains); and maintains that it is as easy to speak of the continuity of the cell-body as of that of the nuclear substance, and that the one may transmit heritable qualities to progeny as well as the other. I quite understand that a botanist may easily be led to this view; and Prof. Vines is not the only one to hold it. Waldeyer ("Ueber Karyokinese und ihre Beziehung zu den Befruchtungsvorgängen," Arch. mikr. Anat., xxxii, 1888) has considered the observed facts insufficient to justify the regarding of the nuclear loops as idioplasm; Whitman ("The Seat of Formative and Regenerative Energy," Boston, 1888) among zoologists has expressed himself against this view, and the same occurs in the recent book of Geddes and Thomson ("The Evolution of Sex," London, 1889). The facts which led me to the idea that the nuclear threads were the real carriers of heredity-were, in fact, the idioplasma-are enumerated in Essay IV.; they were primarily the observations of E. van Beneden on the phenomena of fertilization in the ovum of Ascaris megalocephala, those of Strasburger on fertilization in the Phanerogams by a mere nucleus, and the researches of Nussbaum and Gruber on division in the Infusoria. One may further cite as of essential importance the facts of karyokinesis per se, and the circumstance that, only on the supposition that the nucleus contains the idioplasma can the extrusion of polar bodies from the animal ovum be rendered comprehensible. The latter process divides the nuclear substance of the ovum into two quantitatively equal halves, but the body of the ovum into two unequal halves, the size of which is different in every species. The essential part of the process must the refore be the division of the nuclear substance, not that of the cell-mass. These facts on reflection so completely convinced me that the nucleus alone acts as carrier of hereditary tendencies, that the theory of the physiological equality of the nuclei of the sexual elements which I had propounded ten years before (1873) struck me as a certainty; and I then advanced the theory of fertilization which is contained on p. 246 of Essay IV. I believe that till recently Strasburger and I alone had expressed similar views of the essence of fertilization, at least so far as relates to the homodynamy of the sexual nuclei. That most distinguished observer, E. van Beneden, who has won such renown in the investigation of the process of fertilization, took his stand with regard to its theoretical significance on the platform of the older view, which regarded it as the union of two elements intrinsically and essentially the opposite of each other. He could not free himself from that dominant and deeply rooted idea, that the difference between the sexes is something fundamental, an essential principle of existence. The fertilized oosperm is in his eyes a hermaphrodite object, uniting in itself both male and female essences, an idea which many other observers (cf. Kölliker, "Die Bedeutung der Zellenkerne für die Vorgänge der Vererbung," Zeit. wiss. Zool., xlii., 1885) have followed him, and of which the logical sequence is that all the cells of the body are to be regarded as hermaphrodite!

Van Beneden was also influenced by the idea which sways the naturalists of so many countries, that fertilization is a process of rejuvenescence, in the sense that without it life cannot be prolonged to the end. Many still hold to this idea; Maupas ("Recherches expér. sur la multiplication des infusoires ciliés," Arch. zool. exp. gén., (2) vi.p. 165) very recently believed that he had found a proof of its correctness, and attempted to show that Infusoria, for a continuance of existence, must from time to time enter into conjugation, or die from internal causes if this conjugation be prevented. Even were his observations correct, they would still fall short of proving his conclusions; they would prove 
nothing against the immortality of the Protozoa, or for a rejuvenescence in the sense here intended; they would rather state the platitude that ovum and spermatozoon must die, if the condition of their continued existence, namely fusion, inevitable in most species of plants and animals, be prohibited; but this is an accidental, not a natural, death. Richard Hertwig ("Ueber die Conjugation der Infusorien," München, 1889) has also briefly shown that the facts, on which Maupas bases his inference, are not universally true; that Infusoria hindered from conjugation do not die, but increase by division, and may produce whole colonies of animals-nay, that they are generally thus rendered abnormally prolific.

I am distinctly opposed to the rejuvenescence theory, whether applied to unicellular or multicellular organisms; my view is expressed in Essay IV., and may be summarized in this position - we should no longer speak of the conjugating nuclei of the sexual elements as male and female, but as paternal and maternal, there is no opposition of the one to the other, they are essentially alike, and differ only so far as one individual differs from another of the same species. Fertilization is no process of rejuvenescence, but merely a union of the hereditary tendencies of two individuals; tendencies which are bound up with the matter of the nuclear loops; the cell-body of the ovum and spermatozoon is indifferent in this connection, and plays merely the part of a nutritive matter which is modified and shaped by the dominant idioplasm of the nucleus in a definite way, as clay in the sculptor's hand. The different appearance and function of ovum and spermatozoon, and their mutual attraction, rest on secondary adaptations, qualified to ensure that they shall meet and that their idioplasmata shall come into contact, \&c.; and as with the cells, so the differentiation of persons into male and female is also secondary; all the numerous differences of form and function which characterize sex in the higher animals, the so-called "secondary sexual characters," which reach even into the highest spiritual regions of mankind, are nothing but adaptations to ensure the union of the hereditary tendencies of two individuals.

These are briefly the views of fertilization which I have indicated since 1873 , but have only published in a finished and definite shape since the discovery by van Beneden of the morphological processes in the fertilization of the ovum of Ascaris (Essay IV., 1885). I concluded then with these words: "If it were possible to introduce the female pro-nucleus of an egg into another egg of the same species, immediately after the transformation of the latter into the female pro-nucleus, it is very probable that the two nuclei would conjugate just as if a fertilizing spermnucleus had penetrated [the ovum]. If this were so, the direct proof that egg-nucleus and sperm-nucleus are identical would be furnished. Unfortunately the practical difficulties are so great that it is hardly possible that the experiment can ever be made; but such want of experimental proof is partially compensated by the fact, ascertained by Berthold, that in certain Algae (Ectocarpus and Scytosiphon) there is not only a female, but also a male parthenogenesis; for he shows that in these species the male germ-cells may sometimes develop into plants, which however are very weakly."

I have since attempted to fertilize one frog's egg with the nucleus of another; the experiment was, as one would expect, not successful, owing to the enormous havoc caused by introducing a cannula into the egg; but Boveri ("Ein geschlechtlich erzeugter Organismus ohne mütterliche Eigenschaften," Ges. Morph. Physiol. München, 16 Juli, 1889) was more fortunate, in finding an object which allowed of the converse experiment to mine; following Hertwig's example, he removed the nucleus from an Echinoid ovum by agitation, and brought such denucleated ova to develop by introducing spermatozoa. From the spermatozoan nucleus was formed a regular segmentation-nucleus, the embryogenesis pursued its regular course, and there was formed a complete though small freeswimming larva, which lived for a week. From this experiment alone it follows that the views of Strasburger and myself on fertilization are correct, viz. that the sperm-nucleus can play the part of ovum-nucleus and vice versâ, and the older view, to which Prof. Vines ("Lectures on the Physiology of Plants," Cambridge, 1886, pp. 638-681) has also sworn allegiance, must be given up.

An interesting and important modification of Boveri's experiment confirmed both this experiment, and also, if it were necessary, the recognition of the nuclear substance as idioplasm, as maintained by O. Hertwig, Strasburger, and myself. If eggs of Echinus microtuberculatus, when artificially deprived of their nuclei, be fertilized with the spermatozoa of Sphoerechinus granulatus, larvae are developed with the true characters of the second species - that is to say, they have derived everything from the father, nothing from the mother; the nuclear substance alone it is which transmits heredity, and by it the cell-mass is dominated.

I have interpreted the first polar body of the Metazoan ovum as a carrier of ovogenous plasm, which has to be removed from the ovum in order that the germ-plasm may attain the predominance. It is possible that this explanation is not correct; the most recent researches on the conjugation of Infusoria, as expressed in the splendid memoirs of Maupas and R. Hertwig, argue against my interpretation; but the idea which lay at the bottom of this explanation is justified. As it is the nuclear matter which gives to the cell-body its specific character, the ovum must, previous to fertilization, be dominated by a different idioplasm to the sperm-cell, since they are, up to this point, different in appearance and function. On the other hand, when they have united, they contain the same idioplasm-namely, germ-plasm; the consequence is that the first dominant idioplasm is different to that of a later period. This was the idea at the bottom of my explanation of the first polar body, and it is correct. One might| perhaps imagine that the idioplasmata of ovum and spermatozoon were originally different, but that both possessed the power of alteration into germ-plasm; but it would be then incomprehensible why parthenogenetic ova should expel one polar body. Both facts, however, are explicable, if ovum and spermatozoon are dominated up to the period of maturation by different histogenetic idioplasmata with which a small quantity of germ-plasm is mingled, and if at a later period the former be removed and the germ-plasm come to rule in both cells. This process would be by no means abnormal and unparalleled, since entirely analogous divisions of the idioplasm into qualitatively dissimilar portions must occur hundreds of times in every embryogenesis. However, I am most willing to allow that the last word has not yet been said on this question, and would only maintain that my theory of heredity is not concerned thereby. It is not the interpretation of the first polar body, but that of the second, which is decisive; and one can none the less easily think of the latter as a halving of the number of ancestral germ-plasmata, even if it be proved that my explanation of the first polar body was erroneous. I would then express the first division merely as introductory to the second, as the necessary first step in the reduction of ancestral plasmata, the necessity for which we should thus perhaps learn to understand.

The regular modification of idioplasma during the ontogeny, which I have maintained and which so many have attacked (Kölliker ${ }^{1}$ with special vehemence) will now stand out as justified. If the nucleus of a sperm-cell is capable of impressing on the denucleated mass of an ovum its own inherited tendencies, and of calling into being an organism with specific characteristics purely paternal, it will be found difficult to explain the ontogeny otherwise than as a regular modification of the idioplasm, continuous from one cell-division to another, which stamps on the body of each separate cell at each stage its peculiar character, not only with regard to shape but also to function, and especially with regard to the "rhythm" of cell-division.

A further objection is directed by Prof. Vines against my views on the origin of variation. In the fifth essay I have sought the significance of sexual reproduction in the fact that it alone could have called into existence that multiplicity of form of the higher animals and plants, and that constantly fluctuating union of individual variations, of which natural selection stood in need for the creation of new species. I am still of the opinion that the origin of sexual reproduction depends on the advantage which it affords to the operation of natural selection; nay, I am completely convinced that only through its introduction was the higher development of the organic world possible. Still, I am at present inclined to believe that Prof. Vines is correct in questioning whether sexual reproduction is the only factor which maintains Metazoa and Metaphyta in a state of variability. I could have pointed out in the English edition of my "Essays" that my views on this point had altered since their publication; my friend Prof. de Bary, too early lost to science, had already called my attention to those parthenógenetic Fungi which Prof. Vines justly cites against my views; but I desired, on grounds already mentioned, to undertake no alteration in the essays. Besides, I was well aware when the essay was first committed to paper (1886) that my current view on the radical cause of variation was possibly incomplete; and so, in order to expose the truth of the view as far as 
possible to a general test, I drove its logical consequences home, and enunciated the statement that species reproducing parthenogenetically could not be modified into new species. I also began myself at that time experiments on the variation of parthenogenetic species which are still being continued, and on which on some future occasion I hope to be able to report.

Even if, however, from our present knowledge it is probable that sexual reproduction is not the sole radical cause of variability of the Metazoa, still no one will dispute that it is a most active means of heightening variations and of mingling them in favourable proportions. I believe that the important part which this method of reproduction has played in calling out the existing processes of selection, is hardly diminished, even if one grants that direct influences upon the idioplasm call forth a portion of individual variability. Prof. Vines even holds it probable "that the absence of sexuality in these plants [Fungi] may be just the reason why no higher forms have been evolved from them, for in this respect they present a striking contrast to the higher Algae in which sexuality is well marked." But when Prof. Vines says, "there can be no doubt that sexual reproduction does very materially promote variation," he does not mean to say that this is a self-evident proposition; he is well aware that prominent investigators like Strasburger see in sexual reproduction the reverse action, that of maintaining the constancy of the specific character. But I gladly accept his agreement with my view, which confirms the main position of the fifth essay, which runs: Sexual reproduction has arisen by and for natural selection as the sole means by which individual variations can be united and combined in every possible proportion.

With reference also to the problem of the inheritance of acquired (somatogenic) characters, Prof. Vines is again my opponent; he holds that such inheritance is possible. I have denied it, because it did not appear to me self-evident-as was formerly universally assumed - but rather utterly unproven; and because I think that completely unfounded assumptions of such far-reaching consequence should not be made, when requiring a large number of improbable hypotheses for their explication. I have tested all the available evidence for such inheritance as accurately as I could, and have found that none has the value of proof. There is no inheritance of mutilations, and this constitutes up to now the only basis of fact for the supposition of the inheritance of somatogenic variations. If, in the last essay, I have not denied every possibility of such a transmission, Prof. Vines should interpret that in my favour, not to my discredit; it is not the business of an investigator to set forth a proposition, which on the existing evidence he is compelled to believe, as an infallible dogma. Prof. Vines finds my "statements of opinion so fluctuating that it is difficult to determine what [my] position exactly is," but he could have easily discovered my meaning, if, instead of promiscuously contrasting the eight essays and the eight years of their production, he had merely brought the last of them to the bar of judgment. This essay is especially concerned with "the supposed transmission of mutilations," and at its conclusion my verdict on the state of the problem of the inheritance of acquired characters is thus summarised:- "The true decision as to the Lamarckian principle [lies in] the explanation of the observed phenomena of transformation.... If. as I believe, these phenomena can be explained without the Lamarckian principle, we have no right to assume a form of transmission of which we cannot prove the existence. Only if it could be shown that we cannot now or ever dispense with the principle, should we be justified in accepting it." The distinguished botanist De Vries has proved that certain constituents of the cell-body, e.g. the chromatophores of Algae, pass directly from the maternal ovum to the daughter-organism, while the male germ-cell generally contains no chromatophores. Here it appears possible that a transmission of somatogenic variation has occurred; in these lower plants, the separation between somatic and reproductive cells is slight, and the body of the ovum does not require a complete chemical and physical alteration to become the body of the somatic cell of the daughter. But how does this affect the question whether, for instance, a pianoforte player can transmit to his progeny that strength of his fingermuscles which he has acquired by practice? How does this result of practice arrive at the germ-cells? In that lics the real problem which those have to solve who maintain that somatogenic characters are transmissible.

It is proved by the observations of Boveri, quoted above, that among animals the body of the ovum contributes nothing to inheritance. If the transmission of acquired characters should take place, it would have to be by means of the nuclear matter of the germ-cells - in fact, by the germplasm, and that not in its patent, but in its latent condition.

To renounce the principle of Lamarck is certainly not the way to facilitate the explanation of the phenomena; but we require, not a mere formal explanation of the origin of species of the most comfortable nature, but the real and rightful explanation. We must attempt, therefore, to elucidate the phenomena without the aid of this principle. and I believe myself to have made a beginning in this direction. A short time ago I tried this in one of those cases where one would least expect to be able to dispense with the principle of modification by use-namely, in the question of artistic endowment. I proposed to myseif the question whether the musical sense of mankind could be conceived of as arising without a heightening of the original acoustic faculty by use. But even here I came to the conclusion that, not only do we not need this principle, but that use has actually taken no part in the development of the musical sense."

A. WEISMANN

\section{References}

Bell E, Marek LF, Levinstone DS, Merrill C, Sher S, Young IT, Eden M (1978) Loss of division potential in vitro: aging or differentiation? Science 202:1158-1163

Bidder GP (1932) Senescence. Br Med J ii:583-585

Bjorksten J (1968) The crosslinkage theory of ageing. J Am Geriatr Soc $16: 408-427$

Brash DE, Hart RW (1978) Molecular biology of aging. In: Behnke JA, Finch CE, Moment GB (eds) The biology of ageing. Plenum Press, New York, pp 57-81

Bunn CL, Tarrant GM (1980) Limited lifespan in somatic cell hybrids. Exp Cell Res 127:385-396

Burnet FM (1974) Intrinsic mutagenesis: a genetic approach to ageing. Wiley, New York

Calow P (1978) Bidder's hypothesis revisited: solution to some key problems associated with general molecular theory of ageing. Gerontology 24:448-458

Carrel A (1912) On the permanent life of tissues outside of the organism. J Exp Med 15:516-527

Charlesworth B (1980) Evolution in age-structured populations. Cambridge University Press, Cambridge

Child CM (1911) A study of senescence and rejuvenescence based on experiments with Planaria dorotocephala. Arch Entw Mech Org 31: $537-616$

Child CM (1915) Senescence and rejuvenescence. University of Chicago Press, Chicago

Cole LC (1954) The population consequences of life history phenomena. Q Rev Biol 29: 103-137

Comfort A (1979) The biology of senescence, 3rd edn. Churchill Livingstone, Edinburgh

Cremer T, Werdan K, Stevenson AFG, Lehner K, Messerschmidt O (1981) Aging in vitro and D-glucose uptake kinetics of diploid human fibroblasts. J Cell Physiol 106:99-108

Curtis HJ (1966) Biological mechanisms of aging. Charles C Thomas, Springfield, Illinois

Cutler RG (1975) Evolution of human longevity and the genetic complexity governing aging rate. Proc Natl Acad Sci USA 72: 4664-4668

Cutler RG (1978) Evolutionary biology of senescence. In: Behnke JA, Finch CE, Moment GB (eds) The biology of aging. Plenum Press, New York

Daniel CW (1973) Finite growth of mouse mammary gland serially propagated in vivo. Experientia 29:1422-1424

Darwin C (1872) The origin of species by means of natural selection, 6 th edn, chap V "Compensation and economy of growth". J Murray, London

De Long R, Poplin L (1977) On the etiology of aging. J Theor Biol 67: $111-120$

Ebeling AH (1913) The permanent life of connective tissue outside of the organism. J Exp Med 17:273-285

1 "Das Karyoplasma und die Vererbung: eine Kritik der Weismann'sche Theorie von der Continuität des Keimplasma's,"Zeit. wiss. Zool., xliv. p. 228,1886 
Epstein CJ, Martin GM, Schultz AL, Motulsky AG (1966) Werner's syndrome: a review of its symptomatology, natural history, pathologic features, genetics and relationship to the natural aging process. Medicine 45: 177-221

Evans CH (1977) Further evidence against the accumulation of altered enzymes in late passage mouse fibroblasts in vitro. Exp Gerontol 12:169-171

Fulder SJ, Holliday R (1975) A rapid rise in cell variants during the senescence of populations of human fibroblasts. Cell 6:67-73

Götte A (1883) Über den Ursprung des Todes. L Voss, Hamburg Leipzig

Guthrie RD (1969) Senescence as an adaptive trait. Persp Biol Med 12: 313-324

Haldane JBS (194I) New paths in genetics. George Allen \& Unwin, London

Hamilton WD (1966) The moulding of senescence by natural selection. J Theor Biol 12: 12-45

Harley CB, Goldstein S (1978) Cultured human fibroblasts: distribution of cell generations and a critical limit. J Cell Physiol 97:509-516

Harley CB, Pollard JW, Chamberlain JW, Stanners CP, Goldstein S (1980) Protein synthetic errors do not increase during aging of cultured human fibroblasts. Proc Natl Acad Sci USA 77: 1885-1889

Harman D (1956) Aging: a theory based on free radical and radiation chemistry. J Gerontol 11:298-300

Hart RW, Setlow RB (1974) Correlation between deoxyribonucleic acid excision-repair and lifespan in a number of mammalian species. Proc Natl Acad Sci USA 71:2169-2173

Hayflick L (1965) The limited in vitro lifetime of human diploid cell strains. Exp Cell Res 37:614-636

Hayflick L (1977) The cellular basis for human ageing. In: Finch CE, Hayflick L (eds) Handbook of the biology of aging. Van NostrandReinhold, New York, pp 159-186

Hayflick L, Moorhead PS (1961) The serial cultivation of human diploid cell strains. Exp Cell Res 25:585-621

Hill B, Franks LM (1977) The mechanism of ageing. Trends Biochem Sci $2: \mathrm{N} 80-\mathrm{N} 82$

Hirsch HR (1978) The waste-product theory of ageing: waste dilution by cell division. Mech Ageing Dev 8:51-62

Holliday R (1974) Growth and death of diploid and transformed human fibroblasts. Fedn Proc 34:51-55

Holliday R (1979) A new theory of carcinogenesis. Br J Cancer 40: $513-522$

Holliday R, Tarrant GM (1972) Altered enzymes in ageing human fibroblasts. Nature 238:26-30

Holliday R, Kirkwood TBL (1981) Predictions of the somatic mutation and mortalisation theories of cellular ageing are contrary to experimental observations. J Theor Biol 93:627-642

Holliday R, Porterfield JS, Gibbs DD (1974) Premature ageing and occurrence of altered enzyme in Werner's syndrome fibroblasts. Nature 248:762-763

Holliday R, Huschtscha LI, Tarrant GM, Kirkwood TBL (1977) Testing the commitment theory of cellular aging. Science 198:366-372

Holliday R, Huschtscha LI, Kirkwood TBL (1981) Cellular aging: further evidence for the commitment theory. Science 213:1505-1508

Illmensee K, Stevens LC (1979) Teratomas and chimeras. Sci Am 240: $87-98$

Kay HEM (1965) How many cell generations? Lancet ii:418-419

Kirkwood TBL (1977) Evolution of ageing. Nature 270:301-304

Kirkwood TBL (1980) Error propagation in intracellular information transfer. J Theor Biol 82:363-382

Kirkwood TBL (1981) Repair and its evolution: survival versus reproduction. In: Townsend CR, Calow P (eds) Physiological ecology: an evolutionary approach to resource use. Blackwell, Oxford, pp 165-189

Kirkwood TBL, Holliday R (1975) Commitment to senescence: a model for the finite and infinite growth of diploid and transformed human fibroblasts in culture. J Theor Biol 53:48I-496

Kirkwood TBL, Holliday R (1979) The evolution of ageing and longevity. Proc R Soc Lond B 205:531-546

Kontermann K, Bayreuther K (1979) The cellular aging of rat fibroblasts in vitro is a differentiation process. Gerontology 25:261-274

Kram D, Schneider EL (1978) Parental age effects: increased frequencies of genetically abnormal offspring. In: Schneider EL (ed) The genetics of aging. Plenum Press, New York, pp 225-260
Krohn PL (1962) Review lectures on senescence. II. Heterochronic transplantation in the study of ageing. Proc R Soc Lond B 157: 128- 147

Lack D (1954) The natural regulation of animal numbers. Clarendon Press, Oxford

Linn S, Kairis M, Holliday R (1976) Decreased fidelity of DNA polymerase activity isolated from aging human fibroblasts. Proc Natl Acad Sci USA $73: 2818-2822$

Martin GM (1977a) Cellular aging-clonal senescence. Am J Pathol $89: 484-511$

Martin GM (1977b) Cellular aging-postreplicative cells. Am J Pathol 89:513-530

Martin GM (1979) Genetic and evolutionary aspects of aging. Fed Proc 38: 1962-1967

Martin GM, Sprague CA, Epstein CJ (1970) Replicative lifespan of cultivated human cells: effect of donor's age, tissue and genotype. Lab Invest 23:86-92

Martin GM, Sprague CA, Norwood TH, Pendergrass WR (1974) Clonal selection, attenuation and differentiation in an in vitro model of hyperplasia. Am J Pathol 74:137-154

Martin GR (1980) Teratocarcinomas and mammalian embryogenesis. Science 209:768-776

Martinez AO, Norwood TH, Prothero JW, Martin GM (1978) Evidence for clonal attenuation of growth potential in HeLa cells. In Vitro $14: 996-1002$

Maynard Smith J (1962) Review lectures on senescence. I. The causes of ageing. Proc R Soc Lond B 157:115-127

Maynard Smith J (1976) Group selection. Q Rev Biol 51:277-283

Medawar PB (1946) Old age and natural death. Mod Quart 2 (new series) : $30-49$

Medawar PB (1952) An unsolved problem in biology. HK Lewis, London. (Reprinted in "The Uniqueness of the Individual", Methuen, London 1957)

Medvedev ZhA (1962) Ageing at the molecular level. In: Shock NW (ed) Biological aspects of ageing. Columbia University Press, New York, pp 255-266

Medvedev ZhA (1981) On the immortality of the germ line: genetic and biochemical mechanisms-A review. Mech Ageing Dev 17:331-359

Metchnikoff E (1907) The prolongation of life: optimistic studies. Heinemann, London

Minot CS (1907) The problem of age, growth and death. Pop Sci Monthly 70:481-496; 71:97-120; 71:509-523

Morley A, Cox S, Holliday R (1982) Human lymphocytes resistant to 6-thioguanine resistance increase with age. Mech Ageing Dev (in press)

Muggleton-Harris AL, Hayflick L (1976) Cellular ageing studied by the reconstruction of replicating cells from nuclei and cytoplasms isolated from normal human diploid cells. Exp Cell Res 103:321-330

Nienhaus AJ, de Jong B, ten Kate LP (1971) Fibroblast culture in Werner's syndrome. Humangenetik 13:244-246

Ogden DA, Micklem HS (1976) The fate of serially transplanted bone marrow cell populations from young and old donors. Transplantation $22: 287-293$

Orgel LE (1963) The maintenance of the accuracy of protein synthesis and its relevance to ageing. Proc Natl Acad Sci USA 49:517-521

Orgel LE (1973) Ageing of clones of mammalian cells. Nature 243: $441-445$

Pearl R (1928) The rate of living. University of London Press, London

Ponten J, Westermark B (1980) Cell generation and aging of nontransformed glial cells from adult humans. Adv Cellular Neurobiol $1: 209-227$

Rose MR, Charlesworth B (1980) A test of evolutionary theories of senescence. Nature 287:141-142

Rosenberger R, Kirkwood TBL (1982) The stability of the translation apparatus. In: Galas DJ (ed) Accuracy in molecular biology. Marcel Dekker, New York (in press)

Rothfels KH, Kupelwieser EB, Parker RC (1963) Effects of X-irradiated feeder layers on mitotic activity and development of aneuploidy in mouse embryo cells in vitro. Can Cancer Conf 5:191-223

Sacher GA (1978) Evolution of longevity and survival characteristics in mammals. In: Schneider EL (ed) The Genetics of aging. Plenum Press, New York, pp 151-167

Schneider EL, Mitsui Y (1976) The relationship between in vitro cellular aging and in vivo human age. Proc Natl Acad Sci USA 73:3584-3588 
Sheldrake AR (1974) The ageing, growth and death of cells. Nature 250:381-385

Smith JR, Hayflick L (1974) Variation in the life-span of clones derived from human diploid cell strains. J Cell Biol 62:48-53

Smith JR, Whitney RG (1980) Intraclonal variation in proliferative potential of human diploid fibroblasts: stochastic mechanism for cellular aging. Science 207:82-84

Smith JR, Pereira-Smith OM, Schneider EL (1978) Colony size distribution as a measure of in vivo and in vitro aging. Proc Natl Acad Sci USA $75: 1353-1356$

Smith-Sonneborn J (1979) DNA repair and longevity assurance in Paramecium tetraurelia. Science 203:1115-1117

Sonneborn TM (1930) Genetic studies on Stenostomum incaudatum (nov spec). I. The nature and origin of differences among individuals formed during vegetative reproduction. J Exp Zool 57:57-108

Sonneborn TM (1954) The relation of autogamy to senescence and rejuvenescence in Paramecium aurelia. J Protozool 1:38-53

Stanley JF, Pye D, MacGregor A (1975) Comparison of doubling numbers attained by cultured animal cells with lifespan of species. Nature 255:158-159

Stecker E, Gardner HA (1970) Werner's syndrome. Lancet ii : 1317

Stein GH, Yanishevsky RM (1979) Entry into S phase is inhibited in two immortal cell lines fused to senescent human diploid cells. Exp Cell Res 120:155-165

Stevens LC (1967) The biology of teratomas. In: Abercrombie M, Bracket $\mathrm{J}$ (eds) Advances in morphogenesis, vol 6. Academic Press, New York, pp 1-31

Strehler BL (1977) Time, cells and aging, 2nd edn. Academic Press, New York

Swim HE, Parker RF (1957) Culture characteristics of human fibroblasts propagated serially. Am J Hyg 66:235-243

Szilard L (1959) On the nature of the aging process. Proc Natl Acad Sc USA $45: 30-45$

Thompson KVA, Holliday R (1982) Genetic effects on the in vitro ageing of human fibroblasts. I. Werner's syndrome, Cockayne's syndrome and progeria. Gerontology (in preparation)

Todaro GJ, Green H (1963) Quantitative studies of the growth of mouse embryo cells in culture and their development into established lines. J Cell Biol 17:299-313
Topp W, Hall JD, Rifkin D, Levine AJ, Pollack R (1977) The characterisation of SV40-transformed cell lines derived from mouse teratocarcinoma: growth properties and differentiated characteristics. J Cell Physiol 93:269-276

Vines SH (1889) An examination of some points in Prof. Weismann's theory of heredity. Nature 40:621-626

Vogel F, Rathenberg R (1975) Spontaneous mutation in man. In: Harris H, Hirschhorn K (eds) Advances in human genetics, vol 5 . Plenum Press, New York London, pp 223-318

Weismann A $(1889,1891)$ Essays upon heredity and kindred biological problems, vol I (1st edn 1889, 2nd edn 189I). Clarendon Press, Oxford

Weismann A (1892a) Aufsätze über Vererbung und verwandte biologische Fragen. Verlag von Gustav Fischer, Jena

Weismann A (1892b) Essays upon heredity and kindred biological problems, vol II. Clarendon Press, Oxford

Weismann A (1892c) Das Keimplasma: Eine Theorie der Vererbung. Verlag von Gustav Fischer, Jena

Weismann A (1913a) Vorträge über Deszendenztheorie, Vol I (3. Aufl). Verlag von Gustav Fischer, Jena

Weismann A (1913b) Vorträge über Deszendenztheorie, Vol II (3. Aufl). Verlag von Gustav Fischer, Jena

Williams GC (1957) Pleiotropy, natural selection and the evolution of senescence. Evolution 11:398-411

Williamson AR, Askonas BA (1972) Senescence of an antibodyforming cell clone. Nature 238:337-339

Witkowski JA (1980) Dr Carrel's immortal cells. Med Hist 24:129-142

Woolhouse HW (1967) The nature of senescence in plants. In: Woolhouse HW (ed) Aspects of the biology of ageing. Symposia of the Society for Experimental Biology, No XXI. Cambridge University Press, Cambridge, pp 179-213

Zavala C, Herner G, Fialkow PJ (1978) Evidence for selection in cultured diploid fibroblast strains. Exp Cell Res 117:137-144

Zs-Nagy I (1978) A membrane hypothesis of aging. J Theor Biol 75: 189-195

Received November 11 / Revised December 11, 1981 